\title{
Chemokines in COPD: From Implication to Therapeutic Use
}

\author{
Pauline Henrot ${ }^{1,2,3}$, Renaud Prevel 1,2,3 (D), Patrick Berger 1,2,3 (D) and Isabelle Dupin 1,2,*(D) \\ 1 Univ-Bordeaux, Centre de Recherche Cardio-thoracique de Bordeaux, U1045, CIC 1401, F-33604 Pessac, \\ France; pauline.henrot@gmail.com (P.H.); renaud.prevel@hotmail.fr (R.P.); \\ patrick.berger@u-bordeaux.fr (P.B.) \\ 2 INSERM, Centre de Recherche Cardio-thoracique de Bordeaux, U1045, CIC 1401, F-33604 Pessac, France \\ 3 CHU de Bordeaux, Service d'exploration fonctionnelle respiratoire, CIC 1401, F-33604 Pessac, France \\ * Correspondence: isabelle.dupin@u-bordeaux.fr; Tel.: +33-(0)5-47-30-27-51
}

Received: 3 May 2019; Accepted: 3 June 2019; Published: 6 June 2019

\begin{abstract}
Chronic Obstructive Pulmonary Disease (COPD) represents the 3rd leading cause of death in the world. The underlying pathophysiological mechanisms have been the focus of extensive research in the past. The lung has a complex architecture, where structural cells interact continuously with immune cells that infiltrate into the pulmonary tissue. Both types of cells express chemokines and chemokine receptors, making them sensitive to modifications of concentration gradients. Cigarette smoke exposure and recurrent exacerbations, directly and indirectly, impact the expression of chemokines and chemokine receptors. Here, we provide an overview of the evidence regarding chemokines involvement in COPD, and we hypothesize that a dysregulation of this tightly regulated system is critical in COPD evolution, both at a stable state and during exacerbations. Targeting chemokines and chemokine receptors could be highly attractive as a mean to control both chronic inflammation and bronchial remodeling. We present a special focus on the CXCL8-CXCR1/2, CXCL9/10/11-CXCR3, CCL2-CCR2, and CXCL12-CXCR4 axes that seem particularly involved in the disease pathophysiology.
\end{abstract}

Keywords: COPD; chemokines; exacerbation; airway remodeling; chronic inflammation; gradient; biomarker

\section{Introduction}

Lung exposure to various types of noxious particles, such as those present in cigarette smoke, can lead to COPD. COPD is a common and devastating respiratory disease, characterized by a progressive airflow obstruction. COPD has become the third leading cause of global death by 2010, with 2.9 million deaths annually [1]. The Global Burden of Disease Study reports a prevalence of 251 million cases of COPD globally and an incidence of 95 million cases per year in 2016 [2]. In a prospective population-based cohort study with 25 years of follow-up (Rotterdam Study), the prevalence of COPD is $4.7 \%$ and the overall incidence is approximately $9 / 1000$ per year [3]. The major risk factor is cigarette smoke, but there is a wide variety of interindividual responses for the same amount and duration of tobacco smoking. In total, the onset of the disease results from complex interactions between cumulative exposure to air pollutants and factors related to the individual himself, such as genetic factors [4], bronchial hyperresponsiveness [5], poor respiratory function some months after birth [6], or low lung function in early adulthood [7].

The chronic course of the disease is frequently worsened by recurrent episodes of acute worsening of respiratory symptoms, called acute exacerbations, most often related to viral or bacterial infections [8]. Acute exacerbations dramatically affect quality of life and worsen the natural history of the disease: 
Lung function decreases more rapidly in patients with frequent exacerbations, with an increased risk of death [9]. Current pharmacological treatments for COPD patients decrease exacerbation frequency by only up to $29 \%$ compared to a placebo either alone or in combination, but they do not have any significant effect on mortality, as shown by 5 large studies (TOwards a Revolution in COPD Health (TORCH) [10], Understanding Potential Long-term Impacts on Function with Tiotropium (UPLIFT) [11], Study to Understand Mortality and Morbidity in COPD (SUMMIT) [12], EFfect of Indacaterol Glycopyronium Vs Fluticasone Salmeterol on COPD Exacerbations (FLAME) [13], and InforMing the PAthway of COPD Treatment (IMPACT) [14]).

COPD is associated with an early activation of structural (epithelial) and innate immune cells (in particular, macrophages, neutrophils, and eosinophils) within the lung. These early events favor the accumulation of adaptive immune cells $\left(\mathrm{CD}^{+}\right.$and $\mathrm{CD}^{+} \mathrm{T}$ cells and $\mathrm{B}$ cells) in the airways and the alveolar compartments, leading to chronic inflammation [15]. Other distinguishing feature of COPD includes bronchial remodeling and, in particular, peribronchial fibrosis. The origin of peribronchial fibrosis remains controversial: It has been recently suggested that circulating fibrocytes recruited into the lungs could play a role in this process, either directly or indirectly [16]. Although inflammation and remodeling are distinct processes, they are related; on the one hand, the infiltration of inflammatory cells into the lungs can influence cell survival, proliferation, migration and differentiation of structural cells, and on the other hand, the modification of lung architecture could also modify and perpetuate chronic inflammation. This has led some investigators to hypothesize that both chronic inflammation and bronchial remodeling should be targeted by treatment to slow down disease progression.

In this context, molecules of the chemokine family are of particular interest. Chemokines are small molecules ( 8 to $12 \mathrm{kDa}$ ), belonging to the family of cytokines. Because they are implicated in various biological functions such as chemotaxis [17], leukocyte degranulation [18], hematopoiesis [19] and angiogenesis [20], they represent therapeutic targets in numerous diseases, such as breast cancer [21], human immunodeficiency virus (HIV)/acquired immune deficiency syndrome (AIDS) [22], and atherosclerosis [23]. Multiple studies have now established a pivotal role for chemokines in COPD development and progression. This review attempts to highlight important recent advances in this field. In particular, we systematically reviewed chemokines modifications associated with COPD (Table 1), and based on the number of preclinical and clinical evidences as well as recent findings, we focus on the CXCL8-CXCR1/2, CXCL9/10/11-CXCR3, CCL2-CCR2, and CXCL12/CXCR4 axes that seem to be clearly associated with COPD pathophysiology. Research on chemokines and their receptors could pave the way for the development of new strategies of treatments which are urgently needed both to slow the natural course of the disease and to treat acute episodes of exacerbations.

\section{General Considerations on Chemokines in COPD}

\subsection{Chemokines and their Receptors: Definition and Properties, in Relation with COPD}

Chemokines are small molecules that belong to the large family of cytokines. Through their interaction with cell surface G-protein coupled receptors (GPCRs), they mediate various cellular processes, in particular, chemotaxis. Four groups of chemokines (CC, CXC, XC, and CX3C) are defined by the positions of sequentially conserved residues and by their quaternary structures [24]. All chemokines have a highly conserved tertiary structural fold, consisting of a flexible $\mathrm{N}$-terminus and $\mathrm{N}$-terminal loop, followed by a three-stranded $\beta$-sheet with a C-terminal $\alpha$-helix. This conformation allows them to form oligomers, primarily homo, and heterodimers but also tetramers and higher order oligomers [25].

So far, 20 chemokine GPCRs have been described [26]. Like chemokines, they are classified into 4 groups (CCR, CXCR, XCR, and CX3CR). Each chemokine can bind to several receptors of the same group and vice versa. Atypical receptors also exist [27]. At the structural level, the N-terminal part of some GPCR is involved in chemokine interaction, while the tripeptide ELR sequence (Glu-Leu-Arg) of some CXC chemokines was shown to be crucial for binding and activating GPCR. This has allowed the 
distinction between ELR ${ }^{+}$CXC chemokines (CXCL1, 2, 3, 5, 6, 7, and 8), that promote angiogenesis, from $\mathrm{ELR}^{-}$CXC chemokines (CXCL4, 9, 10, and 1) that have angiostatic properties [28]. Other residues such as the Arg-Phe-Phe-Arg-Glu-Ser-His sequence of CXCL12 within the N-loop between the $2 \mathrm{~N}$-terminal cysteines are implicated in GPCR binding. Posttranslational modifications in the N-terminal part of GPCR, such as tyrosine-O-sulfation, participate in the specific interaction between the ligand and the receptor [29] (Figure 1). For example, CXCR4 sulfation at residues 7, 12, and 21 favors the binding of CXCL12 [30].

The binding of the chemokine on its receptor triggers the GDP/GTP exchange of coupled heterotrimeric Gi proteins and the dissociation of the $\beta / \gamma$ subunits. These events induce the activation of Src family kinases, phosphoinositide-specific phospholipase C (PLC) $\beta$, and phosphoinositide 3-kinase (PI3K), with subsequent inositol trisphosphate (IP3)-mediated calcium mobilization and protein kinase C (PKC) activation (for reviews, see References [31,32]). Depending on the considered chemokine receptor, its surface expression, its density, and the cellular context, several downstream signaling pathways can be activated: the mitogen activated protein kinase (MAPK)/extracellular signal-regulated kinase (Erk) signaling pathway, the RhoA pathway, the Janus kinase (JAK)/signaling transducer and activator of transcription (STAT) pathway, and the PI3K/protein kinase B (Akt) pathway. Various biological effects can then be produced, including cell migration and chemotaxis, cell proliferation, and survival. In some cases, the binding of the chemokine does not trigger cell survival: Prolonged exposure to CXCL12 induces apoptosis in T cells [33], colorectal carcinoma cells [34], and acute myeloid leukemia cell lines [35]. Thus, in the context of CXCL12-rich bone marrow, CXCL12 may promote cell apoptosis rather than cell survival, especially if the other pro-survival signals are affected. Importantly, the activation of $\mathrm{G}$ proteins is rapidly attenuated by a negative feedback system, called desensitization, leading to $\beta$-arrestins mediated endocytosis of the receptor [31]. Chemokines receptors can also be regulated by other molecules. For instance, IL-6 regulates CCR5 expression. In a recent study, despite an increased CCR5 expression, monocytes of COPD patients exhibit decreased migratory ability [36].

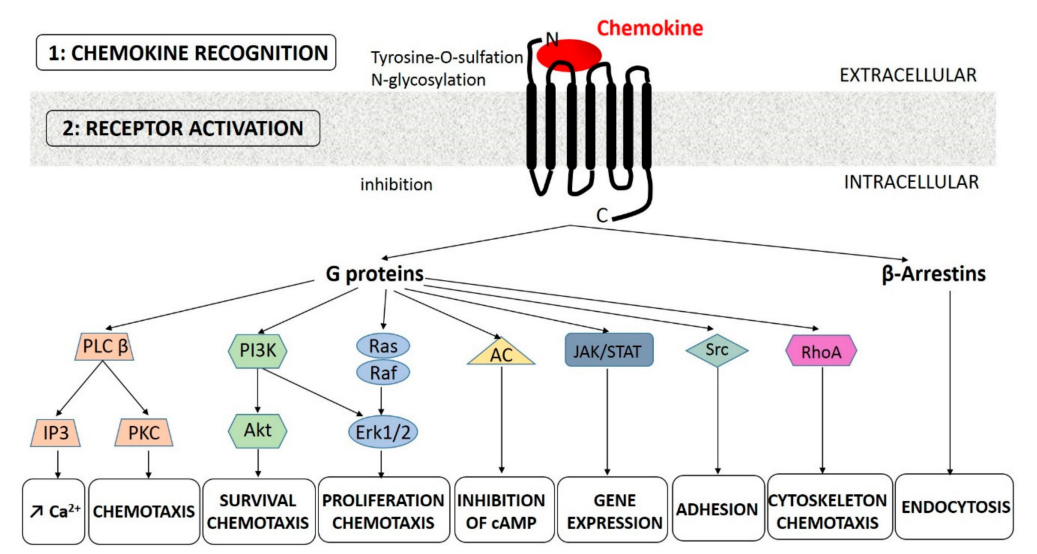

Figure 1. Chemokine-receptor interaction and the activation of downstream signaling pathways. Two main interactions between chemokines and their receptors are generally accepted: The N-terminal region of the chemokine binds in the pocket of the receptor transmembrane helical domain, while the N-terminal region of the receptor binds to a structural loop of the chemokine [37]. Evidence for more interactions has been reported [37]. Posttranslational modifications in the N-terminus part of chemokine receptor, such as tyrosine-O-sulfation and N-glycosylation, can affect this first binding step. A second activation-step then occurs that stabilize the receptor in an active conformation. Knowledge about this two-step mechanism and structural information of the chemokine-receptor interaction has been reviewed recently [38]. AC: Adenylate cyclase, C: C terminus part, IP3: Inositol trisphosphate, JAK/STAT: Janus kinase/signaling transducer and activator of transcription, Erk: Extracellular signal-regulated kinase, N: N terminus part, C: C terminus part, PI3K: Phosphoinositide 3-kinase, PKC, Protein kinase C, PLC: Phosphoinositide-specific phospholipase C. 
Various chemokines are often produced at the target sites of leukocyte trafficking, and combinatorial effects could occur at different levels: Chemokines heterodimers/oligomers can modify biological activity, or each chemokine can act on its respective GPCR to trigger synergistic or antagonistic effect [39]. Chemokines can also interact with endogenous damage-associated molecular patterns (DAMPs), such as high mobility group box 1 protein (HMGB1), an alarmin that enhances the activity of CXCL12 [40] and that protects CXCL12 from degradation [41]. As cigarette smoke exposure and infections promote DAMPs released by damaged cells or by the immune system, this should be taken into account when exploring chemokine function in COPD.

Chemokines also bind strongly to glycosaminoglycans (GAGs), and this interaction can drive chemokines oligomerization [42], which is critical for subsequent biological effects. For example, monomeric and dimeric CXCL12 induce selective signal transduction pathways and differ in $\beta$-arrestin recruitment, and only the monomeric type promotes cell migration [30,43]. For some chemokines such as CCL2, CCL4, and CCL5, GAG binding and oligomerization are required to induce cell recruitment [44]. Specific changes of pulmonary extracellular matrix (ECM) are associated with COPD and occur in all lung compartments [45]. In COPD, the major changes described are a destruction of elastic fibers, as well as elevated levels of hyaluronan (belonging to the GAG family) and tenascin $\mathrm{C}$ with decreased level of decorin. Interestingly, an accelerated turnover of ECM proteins has been evidenced during acute exacerbations of COPD, which could further affect chemokine expression levels and localization patterns [46]. In addition, chemokines are the target of numerous proteases, such as MMP-1, 2, 3, 9, 13, and 14; cathepsin; elastase; and DPPIV/CD26 for CXCL12. Tissue decomposition in emphysema is usually described as a result of an imbalance between protease and antiprotease activities that could also have direct implication on chemokines degradation.

Of note, the conservation of the chemokine expression pattern between human and rodent models (essentially mice) has not been thoroughly investigated in COPD. However, some studies aiming to compare the expression of specific chemokines in other contexts have shown a poor correlation between human and mice in the basal state $[47,48]$. Therefore, conclusions drawn from murine models should be taken with caution.

\subsection{Chemokines Gradients in COPD}

Chemokine receptor expression allows the cell to sense and to respond to a concentration gradient. While chemokines and their receptors are well-described, literature on gradients is much sparser. One of the key problems is to measure in vivo the concentrations and their dynamics to characterize chemokine gradients. In addition, the microenvironment constantly evolves, leading to temporal and spatial modification of graded signals.

Another important distinction is to know whether the considered gradient is in the fluid phase or is a gradient of immobilized chemokines by their interaction with the ECM molecules, especially GAGs. Pioneer studies, such as those performed on CCL21 mediated dendritic cell migration [49], have provided in vivo pieces of evidence of directional migration along gradients of tissue immobilized chemokines. Because chemokines have short half lives in solution, soluble gradients may be more transient, but the cues may play a role at longer range that immobilized chemokines. In the context of COPD, both immobilized and soluble gradients probably coexist. While immobilized gradients are in principle more stable and robust that soluble gradients, both are probably differently modified by COPD exacerbation.

We also propose to distinguish intra-tissue gradients from inter-tissue gradients. At the organism level, inter-tissue gradients might play a critical role in orchestrating cell trafficking between bone marrow, lymph nodes, peripheral circulation, the lungs, and the heart. In peripheral circulation, chemokines are present both in solution and immobilized on the endothelial cell surfaces, where they can trigger leukocyte arrest and extravasation. In principle, these gradients should be evidenced by measuring chemokines concentration in different organs, as already done for CXCL12 in the 
context of idiopathic pulmonary fibrosis [50]. On the other hand, intra-tissular gradients, particularly intrapulmonary gradients, are probably mostly composed of chemokines bound to the ECM.

A consideration at the gradient level is key to understand in vivo effects. For example, neutrophil recruitment to the lungs is increased in response to mutant CXCL8 that binds less strongly to the GAGs [51]. This surprising effect has been explained by tissue-specific differences in GAG interactions: The mutant CXCL8 is less active in the peritoneum but more active in the lungs. Finally, the kinetics of gradient formation, strongly regulated by the kinetics of the interaction between chemokines and GAGs is another important point to consider [52]. This has important consequences during COPD exacerbation: Chemokines that bind to GAG with rapid kinetics will form gradients slowly and vice versa, leading to potential early and late effects.

\section{Chemokines at the Stable State and During Exacerbation}

COPD pathophysiology is related with small airways inflammation, which is associated with increased numbers of macrophages and $\mathrm{T}$ cells (mostly $\mathrm{CD}^{+} \mathrm{T}$ cells) and, in more severe disease, increased numbers of B cells within the parenchyma and neutrophils in the lumen [15]. In the respiratory tract, cigarette smoke and other irritants might activate alveolar macrophages and airway epithelial cells to release chemotactic factors that then attract circulating leukocytes to the lungs. Eosinophils, innate immune cells, can also be found in the blood and in lung tissue in a proportion of patients with COPD [53]. The natural history of COPD is often marked by periodic exacerbations, characterized with a worsening of the functional respiratory state, as well as an increased sputum production [54]. These exacerbations can be triggered by environmental (air pollution and meteorological effect) or infectious (bacteria and viruses) factors [8]. These factors can trigger the release of damage-associated molecular patterns (DAMPs) which, by binding to specific pattern recognition receptors (PRRs), induce the release of chemotactic factors by resident cells. Therefore, chemokines, produced by various cell types both in the lung and in the systemic circulation (see Table 1 for details), play a key role in orchestrating the chronic inflammation in the lungs of COPD patients. 
Table 1. Chemokines implicated in Chronic Obstructive Pulmonary Disease (COPD).

\begin{tabular}{|c|c|c|c|c|c|c|c|}
\hline Attracting Cells & Expressing Cells & Chemokine & Receptor & $\begin{array}{l}\text { Studied } \\
\text { Site/Organ }\end{array}$ & Model & Result & Ref. \\
\hline $\begin{array}{l}\text { Neutrophils > } \\
\text { monocytes }\end{array}$ & Macrophages, mast cells & $\begin{array}{c}\text { CXCL1 } \\
\text { (GROalpha) }\end{array}$ & $\mathrm{CXCR} 2>\mathrm{CXCR} 1$ & Sputum & Human & Increased in COPD compared to IP & {$[55,56]$} \\
\hline $\begin{array}{c}\text { Neutrophils > } \\
\text { monocytes }\end{array}$ & Macrophages, mast cells & $\begin{array}{l}\text { CXCL2 (MIP-2, } \\
\text { GRObeta) }\end{array}$ & CXCR2 & BALF & Mouse & Increased in COPD compared to control & [57] \\
\hline $\begin{array}{l}\text { Neutrophils > } \\
\text { monocytes }\end{array}$ & $\begin{array}{l}\text { Alveolar macrophages, epithelial } \\
\text { cells, platelets }\end{array}$ & $\begin{array}{l}\text { CXCL5 (epithelial } \\
\text { neutrophil-activating } \\
\text { peptide 78) }\end{array}$ & CXCR2 & $\begin{array}{l}\text { Bronchial } \\
\text { epithelium }\end{array}$ & Human & $\begin{array}{l}\text { Increased at the mRNA level in severe exacerbatory COPD patients } \\
\text { compared to stable COPD patients and controls }\end{array}$ & [58] \\
\hline $\begin{array}{l}\text { Neutrophils > } \\
\text { monocytes }\end{array}$ & $\begin{array}{l}\text { Inflammatory cells, fibroblasts, } \\
\text { endothelial cells, platelets }\end{array}$ & $\begin{array}{l}\text { CXCL7 (truncation } \\
\text { product of } \\
\text { CTAP-III) }\end{array}$ & CXCR2 & Bronchial mucosa & Human & $\begin{array}{l}\text { Increased number of CXCL7+ cells/mRNA level in stable severe COPD } \\
\text { patients compared to healthy controls }\end{array}$ & [59] \\
\hline \multirow{4}{*}{$\begin{array}{c}\text { Neutrophils > } \\
\text { monocytes }\end{array}$} & \multirow{4}{*}{$\begin{array}{l}\text { Neutrophils, epithelial cells, } \\
\text { macrophages, fibroblasts, airway } \\
\text { smooth muscle cells }\end{array}$} & \multirow{4}{*}{ CXCL8 (IL-8) } & \multirow{4}{*}{$\begin{array}{l}\text { CXCR1 } \\
\text { CXCR2 } \\
\text { CCR2 }\end{array}$} & Lung fibroblasts & \multirow{4}{*}{ Human } & Increased & \multirow{4}{*}[58,60-67]{} \\
\hline & & & & Blood & & Increased in COPD compared to asthma & \\
\hline & & & & Induced sputum & & $\begin{array}{l}\text { Increased in COPD patients compared to controls (smokers and } \\
\text { nonsmokers) and asthma }\end{array}$ & \\
\hline & & & & Lung & & Increased in bronchiolar epithelium at the mRNA level & \\
\hline \multirow{3}{*}{$\begin{array}{l}\text { Th1 lymphocytes, Tc1 } \\
\text { lymphocytes, B } \\
\text { lymphocytes }\end{array}$} & \multirow{3}{*}{$\begin{array}{l}\text { Macrophages, dendritic cells, } \\
\text { bronchial epithelial cells }\end{array}$} & \multirow{3}{*}{ CXCL9 (MIG) } & \multirow{3}{*}{ CXCR3 } & Lung section & Human & $\begin{array}{l}\text { CXCL9 expressed in and around lung lymphoid follicles; - CXCR3 } \\
\text { expressed in lung lymphoid follicles, correlated with GOLD stage, } \\
\text { inversely correlated with FEV1 }\end{array}$ & \multirow{3}{*}{ [68-70] } \\
\hline & & & & Sputum & Human & $\begin{array}{l}\text { Increased in the sputum of patients with COPD when compared with } \\
\text { nonsmokers (but not smokers without obstruction) }\end{array}$ & \\
\hline & & & & Bone marrow & Guinea pig & $\begin{array}{l}\text { Decreased at the mRNA level in the bone marrow of CS-exposed } \\
\text { guinea pigs compared to controls }\end{array}$ & \\
\hline \multirow{3}{*}{$\begin{array}{l}\text { Th1 lymphocytes, Tc1 } \\
\text { lymphocytes, B } \\
\text { lymphocytes }\end{array}$} & \multirow{3}{*}{$\begin{array}{l}\text { Macrophages, dendritic cells, } \\
\text { bronchial epithelial cells }\end{array}$} & \multirow{3}{*}{ CXCL10 (IP-10) } & \multirow{3}{*}{ CXCR3 } & Lung section & \multirow{3}{*}{ Human } & $\begin{array}{l}\text { CXCL10 expressed in and around lung lymphoid follicles; also in } \\
\text { bronchiolar epithelium, airway smooth muscle cells }\end{array}$ & \multirow{3}{*}[68,69,71-73]{} \\
\hline & & & & Serum & & Elevated in COPD patients compared to controls & \\
\hline & & & & Sputum & & $\begin{array}{l}\text { Increased in the sputum of patients with COPD when compared with } \\
\text { nonsmokers (but not smokers without obstruction) }\end{array}$ & \\
\hline $\begin{array}{l}\text { Th1 lymphocytes, Tc1 } \\
\text { lymphocytes, B } \\
\text { lymphocytes } \\
\end{array}$ & $\begin{array}{l}\text { Macrophages, dendritic cells, } \\
\text { bronchial epithelial cells }\end{array}$ & CXCL11 (I-TAC) & CXCR3 & Sputum & Human & $\begin{array}{l}\text { Increased in the sputum of patients with COPD when compared with } \\
\text { nonsmokers (but not smokers without obstruction) }\end{array}$ & [68] \\
\hline \multirow{2}{*}{$\begin{array}{l}\text { BM-MSCs, EPCs, HPCs, } \\
\text { lymphocytes, fibrocytes }\end{array}$} & \multirow{2}{*}{$\begin{array}{l}\text { Inflammatory cells, epithelial and } \\
\text { endothelial cells, perivascular } \\
\text { stromal cells, BM-MSCs, }\end{array}$} & \multirow{2}{*}{ CXCL12 (SDF-1) } & \multirow{2}{*}{ CXCR4, CXCR7 } & Bone marrow & Human & $\begin{array}{l}\text { Reduced in COPD BM-MSCs compared to control subjects (mRNA } \\
\text { level) }\end{array}$ & \multirow{2}{*}[74-76]{} \\
\hline & & & & Blood & Mouse & $\begin{array}{l}\text { Enhanced chemosensitivity to CXCL12 of fibrocytes from exacerbating } \\
\text { COPD level of CXCL12 decreased in CS-exposed murine lungs }\end{array}$ & \\
\hline Naïve B cells & Follicular dendritic cells, B cells & CXCL13 & CXCR5 & Serum & Human & Decreased in the serum of BMS-COPD subjects compared to controls & [77] \\
\hline $\begin{array}{c}\text { Leucocytes, } \\
\text { mononuclear cells }\end{array}$ & $\begin{array}{l}\text { Endothelial, epithelial, and } \\
\text { smooth muscle cells; } \\
\text { macrophages, dendritic cells, B } \\
\text { and T cells, and platelets } \\
\text { (transmembrane chemokine) }\end{array}$ & CXCL16 & CXCR6 & Blood & Human & $\begin{array}{l}\text { Percentage of CXCL16 (and CXCR6) expressing platelets is increased in } \\
\text { COPD patients compared to controls }\end{array}$ & [78] \\
\hline
\end{tabular}


Table 1. Cont

\begin{tabular}{|c|c|c|c|c|c|c|c|}
\hline Attracting Cells & Expressing Cells & Chemokine & Receptor & $\begin{array}{c}\text { Studied } \\
\text { Site/Organ }\end{array}$ & Model & Result & Ref. \\
\hline \multirow{4}{*}{$\begin{array}{c}\text { Monocytes }>\mathrm{T} \\
\text { lymphocytes, fibrocytes }\end{array}$} & \multirow{4}{*}{$\begin{array}{l}\text { Alveolar macrophages, T cells, } \\
\text { endothelial and epithelial cells }\end{array}$} & \multirow{4}{*}{ CCL2 (MCP-1) } & \multirow{4}{*}{ CCR2 } & Blood & Human & $\begin{array}{l}\text { Increased in COPD with prevalent emphysema compared to control } \\
\text { subjects }\end{array}$ & \multirow{4}{*}[56,65,66,79,80]{} \\
\hline & & & & Sputum & Human & Increased in COPD compared to nonsmokers and healthy smokers & \\
\hline & & & & Lung & Human & Increased in bronchiolar epithelium at the mRNA level & \\
\hline & & & & $\begin{array}{l}\text { BALF and lung } \\
\text { homogenate }\end{array}$ & Mouse & Increased in CSE-treated mice compared to control group & \\
\hline $\begin{array}{l}\text { Macrophages; Th2 } \\
\text { lymphocytes }\end{array}$ & $\begin{array}{l}\text { Macrophages, lymphocytes, } \\
\text { fibroblasts, epithelial cells }\end{array}$ & $\begin{array}{c}\text { CCL3 } \\
\text { (MIP-1alpha) }\end{array}$ & CCR1, 4,5 & Induced sputum & Human & Increased in COPD patients compared to controls & [81] \\
\hline \multirow{2}{*}{$\begin{array}{l}\text { Macrophages, neutrophils } \\
\text { and dendritic cells; memory } \\
\text { T cells; basophils, } \\
\text { eosinophils; fibrocytes }\end{array}$} & \multirow{2}{*}{$\begin{array}{l}\text { Endothelial cells, smooth muscle } \\
\text { cells; T lymphocytes, epithelial } \\
\text { cells }\end{array}$} & \multirow[t]{2}{*}{ CCL5 (RANTES) } & \multirow[t]{2}{*}{ CCR $1,3,5$} & Bronchial mucosa & \multirow[t]{2}{*}{ Human } & $\begin{array}{l}\text { Increased number of CCL5+ cells/mRNA level in stable severe COPD } \\
\text { patients compared to healthy controls }\end{array}$ & \multirow[t]{2}{*}[59,68]{} \\
\hline & & & & Sputum & & $\begin{array}{l}\text { Increased in the sputum of patients with COPD when compared with } \\
\text { nonsmokers (but not smokers without obstruction) }\end{array}$ & \\
\hline \multirow{3}{*}{$\begin{array}{l}\text { Eosinophils; Th2 } \\
\text { lymphocytes }\end{array}$} & \multirow{3}{*}{$\begin{array}{l}\text { Epithelial cells, endothelial cells, } \\
\text { T lymphocytes, macrophages, } \\
\text { eosinophils }\end{array}$} & \multirow{3}{*}{ CCL11 (Eotaxin-1) } & \multirow{3}{*}{ CCR3 } & BALF & \multirow{3}{*}{ Human } & $\begin{array}{l}\text { Increased in BALF of COPD with a bronchodilator response, and } \\
\text { correlated with emphysema }\end{array}$ & \multirow{3}{*}{ [82-85] } \\
\hline & & & & Blood & & $\begin{array}{l}\text { Increased in COPD (particularly rapidly progressive) compared to } \\
\text { control subjects, and associated with decreased FEV1\% and FEV1/FVC } \\
\text { ratio }\end{array}$ & \\
\hline & & & & Lamina propria & & $\begin{array}{l}\text { Number of eotaxin+ and CCR3+ cells significantly higher in } \\
\text { exacerbated COPD compared to healthy subjects }\end{array}$ & \\
\hline $\begin{array}{c}\text { T cells, } \\
\text { monocytes;Eosinophils; } \\
\text { endothelial cells }\end{array}$ & $\begin{array}{l}\text { Basophils, lung leucocytes, } \\
\text { alveolar macrophages, airway } \\
\text { smooth muscle cells }\end{array}$ & CCL15 & $\mathrm{CCR} 1>\mathrm{CCR} 3$ & Serum & Human & Decreased in the serum of BMS-COPD subjects compared to controls & [77] \\
\hline TH2 lymphocytes & $\begin{array}{l}\text { Dendritic cells, activated } \\
\text { Langerhans cells, airway } \\
\text { epithelial cells }\end{array}$ & CCL17 (TARC) & CCR4 & Serum & Human & $\begin{array}{l}\text { Decreased in the serum of BMS-COPD subjects compared to controls } \\
\text { rs9302690 SNP significantly associated with higher CCL17 levels in } \\
\text { COPD patients }\end{array}$ & {$[77,82]$} \\
\hline $\begin{array}{l}\text { T lymphocytes, immature } \\
\text { dendritic cells }\end{array}$ & $\begin{array}{l}\text { Dendritic cells, monocytes, } \\
\text { alveolar macrophages }\end{array}$ & $\begin{array}{c}\text { CCL18 } \\
\text { (PARC/MIP-4/AMAC }\end{array}$ & 1/DC-CKC1/5CYA-18) & Serum & Human & $\begin{array}{c}\text { Increased in COPD compared to non-obstructive smokers and never } \\
\text { smokers }\end{array}$ & {$[86,87]$} \\
\hline $\begin{array}{l}\text { Naïve T lymphocytes, } \\
\text { mature dendritic cells }\end{array}$ & Fibroblasts & CCL19 & CCR7 & Bone marrow & Human & $\begin{array}{l}\begin{array}{l}\text { Reduced in COPD BM-MSCs compared to control subjects (mRNA } \\
\text { level) }\end{array} \\
\text { (m) }\end{array}$ & [75] \\
\hline $\begin{array}{l}\text { Dendritic cells; neutrophils, } \\
\text { lymphocytes }\end{array}$ & $\begin{array}{l}\text { Airway epithelial cells, } \\
\text { macrophages }\end{array}$ & $\begin{array}{c}\text { CCL20 } \\
\text { (MIP-3alpha) }\end{array}$ & CCR6 & $\begin{array}{l}\text { Total lung and } \\
\text { induced sputum }\end{array}$ & Human & $\begin{array}{l}\text { Increased at the mRNA level in total lung and at the protein level in } \\
\text { induced sputum, compared to never smokers and smokers without } \\
\text { COPD }\end{array}$ & [88] \\
\hline $\begin{array}{l}\text { T lymphocytes, mature } \\
\text { dendritic cells }\end{array}$ & Lymphatic endothelial cells & CCL21 & CCR7 & Bone marrow & Human & $\begin{array}{l}\text { Reduced in COPD BM-MSCs compared to control subjects (mRNA } \\
\text { level) }\end{array}$ & [75] \\
\hline Memory T lymphocytes & $\begin{array}{l}\text { Epithelial cells? (highly produced } \\
\text { by keratinocytes in the skin) }\end{array}$ & CCL27 & CCR10 & Serum & Human & Decreased in the serum of BMS-COPD subjects compared to controls & {$[77]$} \\
\hline T lymphocytes, monocytes & $\begin{array}{l}\text { Mature dendritic cells, } \\
\text { endothelial cells }\end{array}$ & $\begin{array}{c}\text { CX3CL1 } \\
\text { (Fractalkin) }\end{array}$ & CX3CR1 & Serum & Human & Associated with emphysema in chinese COPD patients & [89] \\
\hline
\end{tabular}

COPD: chronic obstructive pulmonary disease; CS: cigarette smoke; IP: interstitial pneumonia; BM-MSCs: bone marrow mesenchymal stem cells; BALF: broncho-alveolar lavage fluid;

BMS: biomass smoke; EPCs: endothelial progenitor cells, HPCs: hematopoietic stem cells, SNP: single nucleotide polymorphism. Expressing cells are from the systemic circulation or lung

cells (other organs are not mentioned) and based on human available data. Additional references for chemokines receptors [24] and attracted cells [90]. 
Of note, the implication of several chemokines in COPD is still controversial. First, many chemokines seem to be associated with smoking status rather than the airflow obstruction characteristic of COPD [82]. For instance, a recent study found that circulating levels of the chemokines CXCL8, CCL4, and CCL22 attain the highest levels in healthy smokers compared to nonsmokers and COPD subjects [91]. The same finding has been observed with CCL17 which has increased mRNA levels in pulmonary cells and in the broncho-alveolar lung fluid (BALF) of COPD patients compared to nonsmokers controls but not compared to current or ex-smokers [92]. Overall, it is likely that some chemokines are increased in smokers compared to nonsmokers, but their levels seem to be further increased in smokers susceptible to develop COPD (for instance, see Reference [93] where CXCL8 levels are increased in smokers with emphysema).

Because some chemokines are continuously expressed while others are specifically induced during exacerbations, we chose here to distinguish chemokine function at a stable state and during an exacerbation. Table 1 presents the list of chemokines modifications associated with COPD, as well as secreting cells and resulting attracted cells. Chemokines receptors implicated in COPD, as well as their connection/interaction with cytokines have been reviewed recently [90]. We then develop hereafter the CXCL8-CXCR1/2, CXCL9/10/11-CXCR3, CCL2-CCR2, and CXCL12-CXCR4 axes that seem to be associated with COPD pathophysiology based on in vitro as well as in vivo findings. Of note, we choose here not to focus on the CCL11-CCR3 axis which might be another key player in COPD, in particular for eosinophil trafficking. Although eosinophil count is emerging as a biomarker, the role of eosinophils as mediator of disease remains to be fully elucidated [53].

\subsection{The CXCL8-CXCR1/2 Axis}

\subsubsection{At the Stable State}

CXCL8 (IL-8) is one of the first intensively studied chemokines and a well-known mediator of neutrophilic inflammation [60,94,95]. It has first been identified as a Lipopolysaccharide (LPS)-stimulated monocyte-secreted factor that stimulated neutrophil exocytosis (granule release) and oxidative burst [96]. It is also the first identified chemokine to play a role in the recruitment of inflammatory cells in COPD: Increased concentrations of CXCL8 have been found in induced sputum of COPD patients compared with smokers with normal lung function and nonsmokers, and these increased CXCL8 levels have been linked with increased neutrophil numbers in sputum [60]. Since then, many studies have confirmed the role of CXCL8 in neutrophilic inflammation occurring in COPD airways. CXCL8 is thought to be produced by alveolar macrophages as well as bronchial epithelial cells [90] (Figure 2). in vitro studies have notably found a secretion by primary bronchial epithelial cell cultures exposed to diesel exhaust [97], as well as an increase in its production by the bronchial epithelial cell line (i.e., BEAS-2B) exposed to small particulate matter [98] and in another bronchial epithelial cell line (16-HBE) stimulated by HSP60 [99]. This production could stimulate the airway epithelium, leading to its contraction and an increased permeability to inflammatory cells [100]. Of note, CXCL8 is also thought to be produced by lung fibroblasts when stimulated by epithelial cell-derived IL-1 $\alpha$ [61] but also by bronchial smooth muscle cells [62] (Figure 2). Some studies have been conducted on mice models and have found that the mouse equivalent of CXCL8 (keratinocyte-derived chemokine) is also increased in the lungs of mice exposed to cigarette smoke extracts (CSE) [101]. 


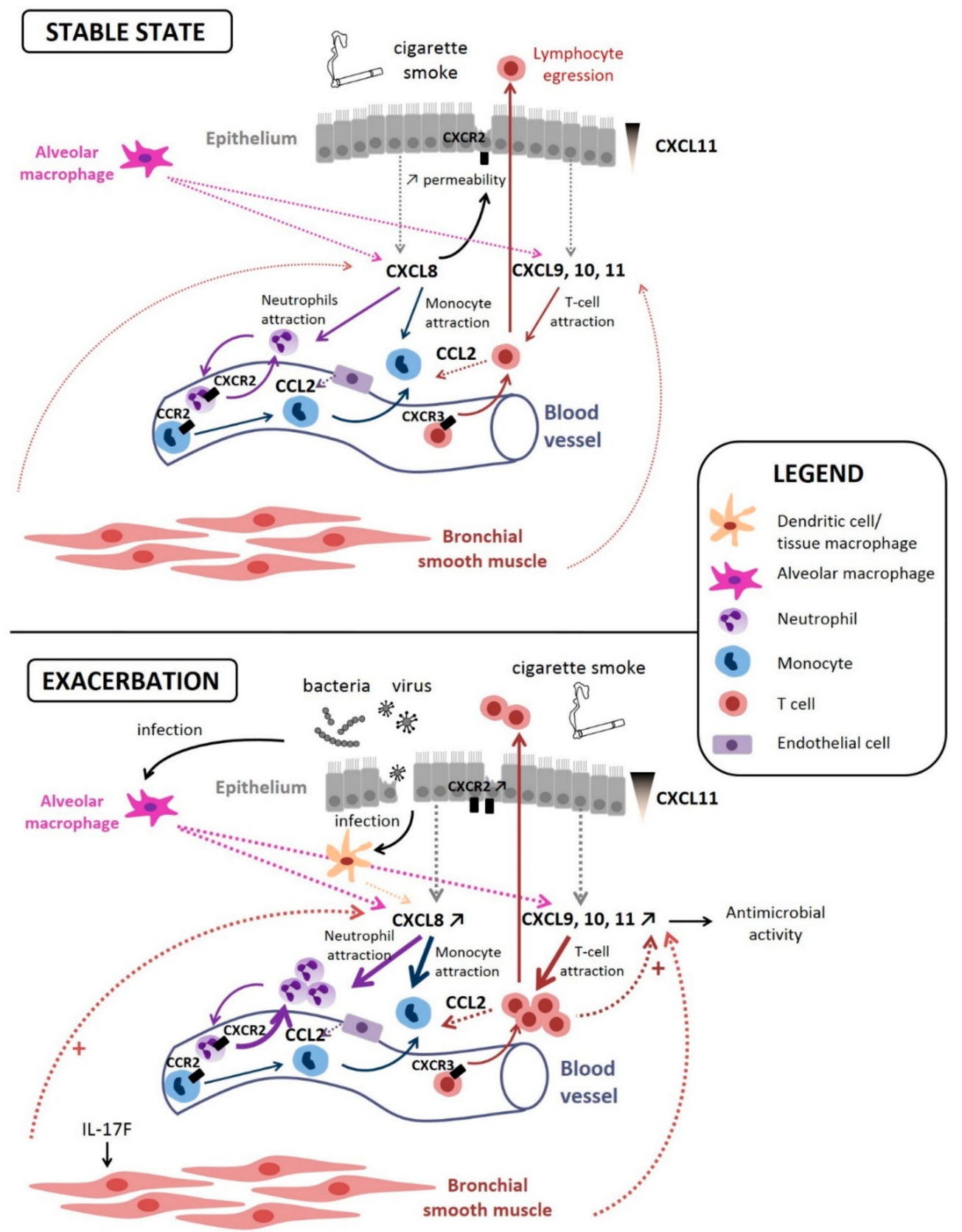

Figure 2. CXCL8-CXCR1/2, CXCL9/10/11-CXCR3, and CCL2-CCR2 axis implications at stable state and during an exacerbation in a COPD lung. At the stable state, CXCL8 (produced by alveolar macrophages, epithelial cells, and bronchial smooth muscle cells) binds on CXCR2 to attract circulating neutrophils and monocytes into the bronchial tissue as well as to increase epithelial cells permeability. CXCL9, 10, and 11 (produced by alveolar macrophages, epithelial cells, and bronchial smooth muscle cells) bind on CXCR3 to attract circulating T cells. A CXCL11 intra-epithelial gradient is responsible for lymphocyte egression towards the lumen. CCL2 (produced by T cells and endothelial cells) binds on CCR2 to attract monocytes. During an exacerbation, production of CXCL8 as well as CXCL9, 10 and 11 is enhanced, which increases the recruitment of monocytes and T cells into the bronchial tissue, participating to the immune (often triggered by microbial infection) response. Chemokines production by bronchial smooth muscle cells can be further enhanced upon IL-17F stimulation. The plain arrows (without other indications) show cell movements; the dotted arrows indicate chemokine secretion.

Overall, cellular crosstalk between alveolar macrophages and epithelial-secreted CXCL8 and CXCR2-expressing neutrophils contributes to COPD physiopathology. 


\subsubsection{During Exacerbation}

The role of CXCL8 in COPD exacerbations has been pointed out several times but not always with the same outcomes. The first study to measure CXCL8 levels during an exacerbation showed an increase in the sputum of exacerbating COPD patients compared to their basal state [102]. Of note, sputum CXCL8 levels correlate with the airways bacterial load and blood myeloperoxidase (a pro-inflammatory enzyme released by neutrophils) levels [103]. Another study showed an increase in serum CXCL8 levels from controls to stable, and exacerbation stage [104]. However, another large-scale study showed that serum CXCL8 is negatively associated with COPD moderate to severe exacerbations within the COPD Gene cohort [82]. Of note, this finding was only observed in one of the two cohorts investigated in this large-scale study. CXCL8 level was also associated with progressive emphysema. Overall, this discrepancy may be related with the fact that CXCL8 has been studied at different sites (serum vs sputum) and/or that the investigated cohorts were different. Finally, another team showed that consistent acute exacerbations ( $\geq 1$ event per year for 3 years) were associated in logistic regression with higher CXCL8 concentrations in the SPIROMICS cohort [105].

The role of CXCL8 in COPD exacerbations is further supported by the correlation of sputum CXCL8 levels with the number of neutrophils [106]. Moreover, CXCR2 (but not CXCR1) mRNA is increased in bronchial epithelial biopsies in exacerbating compared to stable patients [58]. In vitro findings are consistent with these observations, since CXCL8 is upregulated in the human bronchial epithelial cell line (HBE-16) when stimulated by LPS [99].

Finally, CXCL8 is also associated with the IL-17 pathway. Indeed, IL-17F stimulation of human bronchial smooth muscle cells induces the transcription of the CXCL8 gene via the positive transcription elongation factor $b$ (P-TEFb) composed of cyclin T1 and cyclin-dependent kinase 9 (CDK9). IL-17F is able to trigger CDK9 phosphorylation, thus enhancing the production of CXCL8 [107]. This sheds light on different mechanisms by which CXCL8 expression is activated during an exacerbation.

\subsection{The CXCL9/10/11-CXCR3 Axis}

\subsubsection{At the Stable State}

CXCL9, CXCL10, and CXCL11 are mainly produced by alveolar macrophages [108] but also by bronchial epithelial cells $[109,110]$ and bronchial smooth muscle cells [71] (Figure 2). The affinity for their common receptor (CXCR3) is increasing from CXCL9 to CXCL11, suggesting a hierarchy of affinity [111]. Their concentrations are increased in the induced sputum of COPD patients and correlates with the number of neutrophils [68]. However, CXCR3 agonists are mainly known for their ability to attract both Th1 and CD8 ${ }^{+} \mathrm{T}$ lymphocytes (or type 1 cytotoxic T cells) [112]. Peripheral blood mononuclear cells (PBMC) of COPD patients have an enhanced migratory response towards CXCL9, CXCL10, and CXCL11, compared with PBMC from nonsmokers [113], which was apparently not due to an increased number of receptors at the cell surface. Isolated lymphocytes or monocytes from COPD patients do not show enhanced migration towards these chemokines, suggesting that lymphocytes in PBMC are stimulated by the presence of other leukocytes in the PBMC fraction. This concurs with another report that only activated lymphocytes migrate towards CXCL11 [114].

Furthermore, CXCR3 expression is induced on activated Th1 and CD8 $8^{+}$lymphocytes and is thought to be involved in the recruitment of these cells to the sites of inflammation in COPD patients [72]. Moreover, a decline of lung function in COPD patients is associated with a high percentage of $\mathrm{T}$ cells that express CXCR3 [115], suggesting that CXCL9, CXCL10, and CXCL11 may be involved in the recruitment of $\mathrm{T}$ cells and the subsequent immune mediated lung damage observed in COPD, through the production of perforins and granzyme B [116].

By contrast, a CXCL11 gradient in the lungs of COPD patients is also associated with the resolution of pulmonary inflammation. The recruitment of effector T cells to mucosal surfaces, such as bronchial epithelium, is important to provide defense against airway pathogens, but the migration of the lymphocytes from the epithelium to the airways lumen, called "egression", is also physiologically 
crucial to avoid detrimental accumulation of leukocytes within the interstitium. The polarized secretion of CXCL11 at the apical side of bronchial epithelial cells produces a basal-to-apical gradient that triggers lymphocyte egression (Figure 2). This gradient is upregulated in COPD patients [117], resulting in more egression. Thus, the upregulation of CXCL11 production could also be seen as a defense mechanism. This migration may also depend on the underlying stimulus and may vary as the inflammatory responses evolves.

Overall, CXCL9/10/11 produced by macrophages and bronchial epithelial cells act on CXCR3 ${ }^{+}$ cells to recruit inflammatory cells into the lungs, such as T lymphocytes, but CXCL11 seems to be also involved in lymphocyte clearance, emphasizing the possible dual role of chemokines in COPD.

\subsubsection{During Exacerbation}

CXCL10 has been found elevated in the sputum of COPD patients during an exacerbation compared to values after recovery [118]. CXCL10 is also elevated in the serum from COPD patients suffering from a rhinovirus-induced exacerbation compared to control serum [73] and serum CXCL10 has been proposed as a biomarker of virus-associated exacerbations of COPD [119]. In vitro, CXCL9, CXCL10, and CXCL11 are overexpressed when bronchial epithelial cells are stimulated with IFN- $\gamma[109,110]$. Moreover, a release of these three chemokines can be potentiated by the synergistic interactions between TNF- $\alpha$ and IFN- $\gamma[110,120]$. Elevated levels of TNF- $\alpha$ have been found in vivo in the airways of COPD patients [60], and thus, the expression of these three chemokines by structural cells of the airways is likely to drive lymphocyte recruitment during an exacerbation. Finally, T lymphocytes and IFN- $\gamma$-stimulated mononuclear cells also produce these 3 chemokines, and it has been shown that these molecules can also have anti-microbial properties [121].

\subsection{The CCL2-CCR2 Axis}

\subsubsection{At the Stable State}

CCL2 activates CCR2 mainly expressed on monocytes and T cells. In the lungs, CCL2 is mainly produced by alveolar macrophages, $\mathrm{T}$ cells, and endothelial cells, and this increase results in local monocyte recruitment (Figure 2). CCL2 levels have been found to be increased in COPD patients compared to healthy controls in various studies and organs, such as whole blood, induced sputum, and in situ lung tissue (see Table 1). Of note, polymorphisms in the CCL2 gene, as well as in that of CCR2 have been found associated with COPD development [122].

\subsubsection{During an Exacerbation}

CCL2 has been implicated in a systemic inflammatory response (with elevated CCL2 serum level) which may be due to a virus-induced activation of macrophages in virus-infected COPD patients compared to healthy controls [123]. Furthermore, a mouse model of COPD exacerbation (porcine pancreatic elastase (PPE) and LPS-triggered) used to determine the role of IFN regulatory factor III (IRF3) showed a decrease in CCL2 mRNA transcripts in the lungs of IRF3-/- mice. This finding suggests that CCL2 is implicated in LPS/bacteria-induced COPD exacerbation [124].

\subsection{The CXCL12-CXCR4 Axis}

\subsubsection{At the Stable State}

The CXCL12-CXCR4 axis also represents an important chemotactic axis for numerous cells, such as T cells, monocytes, immature B cells, bone marrow-mesenchymal stem cells (BM-MSCs), endothelial progenitor cells (EPCs), and fibrocytes. CXCL12 is expressed by various cells, such as inflammatory cells, bronchial epithelial cells, hematopoietic cells, endothelial cells, and perivascular stromal cells $[125,126]$ and in different tissues, such as the bone marrow, the lungs, and the blood 
vessels. CXCL12 directs stem-cell homing [127] and mediates angiogenesis [128]. Importantly, CXCL12 also binds to CXCR7, a receptor which has been more recently described [129].

Until recently, the role of the CXCL12-CXCR4 axis was unexplored in COPD. In mice exposed to cigarette smoke during 6 months, the level of CXCL12 is decreased in the lungs [74]. In COPD patients, both the number of CXCR4 positive circulating fibrocytes and the blood level of CXCL12 are unchanged at the stable state [76]. However, we very recently demonstrated that bronchial fibrocytes are increased in both distal and proximal airways of COPD patients at a stable state compared to controls [130]. The level of proximal bronchial fibrocytes is correlated with both a loss in lung function (i.e., FEV1 decrease) and bronchial thickness assessed by CT scan [130]. In addition, the level of distal bronchial fibrocytes is correlated with both functional obstruction (i.e., FEV1/FVC decrease) and air trapping assessed by mean lung attenuation during expiration assessed by CT scan [130]. It is thus tempting to speculate that these tissue fibrocytes could participate in tissue repair and bronchial remodeling. By contrast, the levels of both CXCR4 and CXCL12 mRNA are decreased in BM-MSCs of COPD patients [75], suggesting that their chemotactic properties are altered. The migratory and repair capacities of EPCs from COPD patients are also impaired, which could be related to a decreased expression of CXCR4 [131]. An alteration of the CXCR4/CXCL12 axis at the stable state seems, therefore, associated with stem cell senescence and defect in repair function in COPD.

\subsubsection{During Exacerbation}

The level of CXCR4 expressing fibrocytes is enhanced in the blood of COPD patients during an exacerbation, and the chemotactic properties of these cells in response to CXCL12 are also increased [76]. This is apparently not due to a modification of CXCR4 expression level, as the total amount of CXCR4 is not modified in these cells [76]. This is also not related to the blood level of CXCL12, which is not increased during an exacerbation [76]. Such an increased fibrocyte migratory capacity during exacerbation may thus participate to their bronchial infiltration in the airways of COPD patients, even at a stable state (i.e., after exacerbations) [130]. In an influenza-infected mouse model, it has been shown that the neutrophils early recruited within the tissues leave CXCL12-containing trails behind [132]. CXCL12 derived from neutrophils but not from epithelial cells is critical for virus-specific $\mathrm{CD}^{+} \mathrm{T}$ cell recruitment [132]. Altogether, this suggests that the CXCL12-CXCR4 axis is modified during an exacerbation, providing one of the inflammatory cues necessary to guide immune cells into inflamed tissues.

\section{Chemokines in COPD: Therapeutic Implications}

\subsection{Chemokine Levels as Biomarkers in COPD}

Biomarkers in COPD are essential to predict the risk of developing the disease among people exposed to risk factors or to predict the severity of the COPD course. Lungs being at the first line of exposure to airborne particles, lungs biomarkers seem the most fitted option. Sampling can be done in the exhaled breath condensate (easily accessible but low protein content and low reproducibility), induced sputum (noninvasive but requires expertise and time), BALF, lung brushes, and biopsies (the most accurate but all invasive and expensive) [82].

Another option is to measure chemokines level in the blood, hypothesizing that COPD is a systemic disease or at least has features of a systemic disease. Of note, several protein biomarkers measured in the blood are already known: For instance, fibrinogen and C-reactive protein are correlated with COPD severity and risk of exacerbations [133,134]; soluble receptor for advanced glycation end-products (sRAGE) is inversely correlated with emphysema and airflow obstruction [135]; surfactant protein D (SP-D) has been associated with COPD and emphysema [136,137]; and club cell-16 (CC16) might be correlated with airflow obstruction and emphysema [137,138]. The ECLIPSE study has been a breakthrough concerning the assessment of biomarkers in COPD (see Reference [139] for an exhaustive review). Among chemokines, serum CCL18 has been identified as associated with an increased 
risk of cardiovascular hospitalization or mortality [86]. We present hereafter recent data concerning chemokines we have focused on in the previous part.

\subsubsection{CXCL8 as a Biomarker of Disease Severity}

According to Baker et al., CXCL8 belongs to a category of molecules classically associated with cellular senescence, mirroring many inflammatory diseases such as COPD [140]. Indeed, CXCL8 is independently associated with severe COPD, notably worse airflow obstruction (FEV1\% and FEV1/FVC), and with a progression of CT assessed emphysema over 5 years [82].

CXCL8 is also used as a biomarker in murine models of COPD (for instance, to validate the efficiency of a ghrelin-based therapy in a murine model of emphysema [141]).

\subsubsection{CXCL10 as a Genetic Biomarker of Disease Susceptibility}

Polymorphisms in CXCL10 gene promoter could also contribute to susceptibility to COPD: The "rs56061981" single nucleotide polymorphism (SNP) is significantly associated with a reduced risk of developing COPD, and the "rs56216945" SNP is associated with an increased risk; the implicated mechanism could be an alteration of monocyte recruitment [142].

Future research should aim to assess the predictive value of other important chemokines (CCL2, CXCL12 ... ) to determine biomarker combinations in order to better predict personalized risk, as well as to develop new techniques to better assess biomarkers in non-invasive lung samples.

\subsection{Chemokines or Chemokine Receptors Neutralization in COPD}

As several chemokines are implicated in COPD, the neutralization of chemokines and/or their receptors has received considerable interest. Most strategies directly antagonize the GPCR (for excellent review, see Reference [108]). Although very successful in some cases, attested by the example of plerixafor [143] and maraviroc [144], the respective antagonists of CXCR4 and CCR5, most of the pharmacological agents that target chemokine receptors inhibit both $\mathrm{G}$ protein signaling and $\beta$-arrestins-mediated endocytosis, promoting receptor accumulation at cell surface, a process called "antagonist tolerance" [145]. As a result, the efficacy of this type of antagonist is reduced after a long time of treatment. Other molecules, called "biased antagonists", selectively inhibit G protein signalization without preventing $\beta$-arrestins recruitment to the receptor. These biased antagonists could offer in the future a solution for patients developing tolerance. Although in principle more complicated because chemokines are often considered too small and to have too shallow surfaces to be "druggable", recent successes in drug discovery show that chemokines can also be targeted and neutralized [146]. Other approaches include interfering with chemokine-GAG interaction [42] and designing specific chemokine heterodimer agonists [147].

\subsubsection{The CXCL8-CXCR1/2 Axis as Therapeutic Target}

Because neutrophils are often described as the main effector cells of tissue destruction, blocking CXCL8 was expected to lower neutrophilic inflammation and to slow down disease progression. Antibody-mediated blockade of CXCL8 partially inhibits sputum-induced neutrophil chemotaxis [57]. Targeting CXCL8 with an antibody only slightly improves dyspnea in COPD patients [148]. This modest effect can be probably explained by the fact that the antibody only blocks free and not bound CXCL8 and by the existence of other neutrophil chemotactic factors, such as leukotriene B4. Interfering with CXCL8 binding property with GAG could represent an alternative strategy: TNF-stimulated gene/protein-6 (TSG-6) inhibits neutrophil chemotaxis through a direct interaction between TSG-6 and the GAG binding site of CXCL8, which prevents the association of CXCL8 with heparin [149].

Neutralization of the CXCL8 receptors might be more promising. A specific CXCR2 antagonist, SB-332235, decreases neutrophil infiltration into the lungs in a rat model of acute cigarette smoke exposure [150]. In a similar mouse model, $\mathrm{SCH}-\mathrm{N}$, an orally active small molecule inhibitor of CXCR2 also lowers neutrophilic inflammation in the BALF, lung neutrophil infiltration and the level of 
tissue damaging enzymes [151]. In a phase II study, a CXCR2 antagonist, MK-7123, significantly improves the FEV1 and time to the first exacerbation, and it reduces inflammation after 6 months of treatment [152]. Another CXCR2 antagonist, danirixin, has been shown to improve respiratory symptoms and health status of treated patients [153] https://www.zotero.org/google-docs/?s01RNK. Of note, although preclinical evidences are lacking due to species differences in CXCR1, dual CXCR1/2 therapy may be even more effective than selective CXCR2 antagonists [154]. A CXCR1/2 antagonist given orally for 3 days appears to markedly reduce neutrophils and macrophages counts in sputum after inhaled LPS challenge in healthy subjects [155], making it likely that these drugs may reduce pulmonary inflammation in patients with COPD.

\subsubsection{The CXCL9/10/11-CXCR3 Axis as a Therapeutic Target}

Targeting CXCL10 seems an interesting option. An in vitro study has shown that CXCL10-neutralizing antibody can inhibit CSE-induced cell necrosis and activation of inflammatory cytokines in the 16HBE cell line [79]. In the same study, mice treated with CXCL10 neutralizing antibody did not develop COPD features (weight loss; reduction of lung function, increased levels of IL-6, and CCL2 in BALF and lung homogenate) as compared to cigarette smoke-exposed mice. Antagonists of the receptor CXCR3 have been developed [156], but so far, none of them has been tested yet in clinical trials for COPD.

\subsubsection{The CXCL12-CXCR4 Axis as a Therapeutic Target}

The CXCL12-CXCR4 axis is another attractive target, and various strategies of neutralization have already been developed, such as locking CXCL12 in an homodimer structure [157], neutralizing CXCL12 [158-160], interfering with GAG binding properties of CXCL12 [161], and antagonizing CXCR4 by small molecules (for review, see Reference [162]) or blocking antibodies [21]. So far, plerixafor (also called AMD3100; brand name Mozobil) is the only FDA-approved CXCR4 antagonist. It is used to mobilize stem cells from the bone marrow for autologous stem-cell transplantation in patients with multiple myeloma or non-Hodgkin's lymphoma [143]. In a recent study regarding WHIM syndrome, patients have been treated daily by plerixafor at low dose for at least 19 weeks [163], opening perspectives for chronic treatment.

Recent evidences suggest that targeting the CXCL12-CXCR4 axis may be promising for COPD treatment. In a mouse model of cigarette smoke exposure, the intermittent administration of plerixafor decreases emphysema damages, without affecting CXCL12 level and inflammation in BALF [74]. Plerixafor has a protective effect on the number of hematopoietic progenitor cells (HPCs) in the bone marrow following chronic smoke exposure [74] https://www.zotero.org/google-docs/?Ltp2HU, suggesting that increased HPCs available for lung repair might explain, at least partially, the beneficial effect of plerixafor (Figure 3). How plerixafor increases the number of HPCs remains unknown, but it could be explained by the good efficiency of marrow homing of plerixafor mobilized HPCs [164], or it could interfere with CXCL12-mediated apoptosis that have been described in various cells [33-35]. 


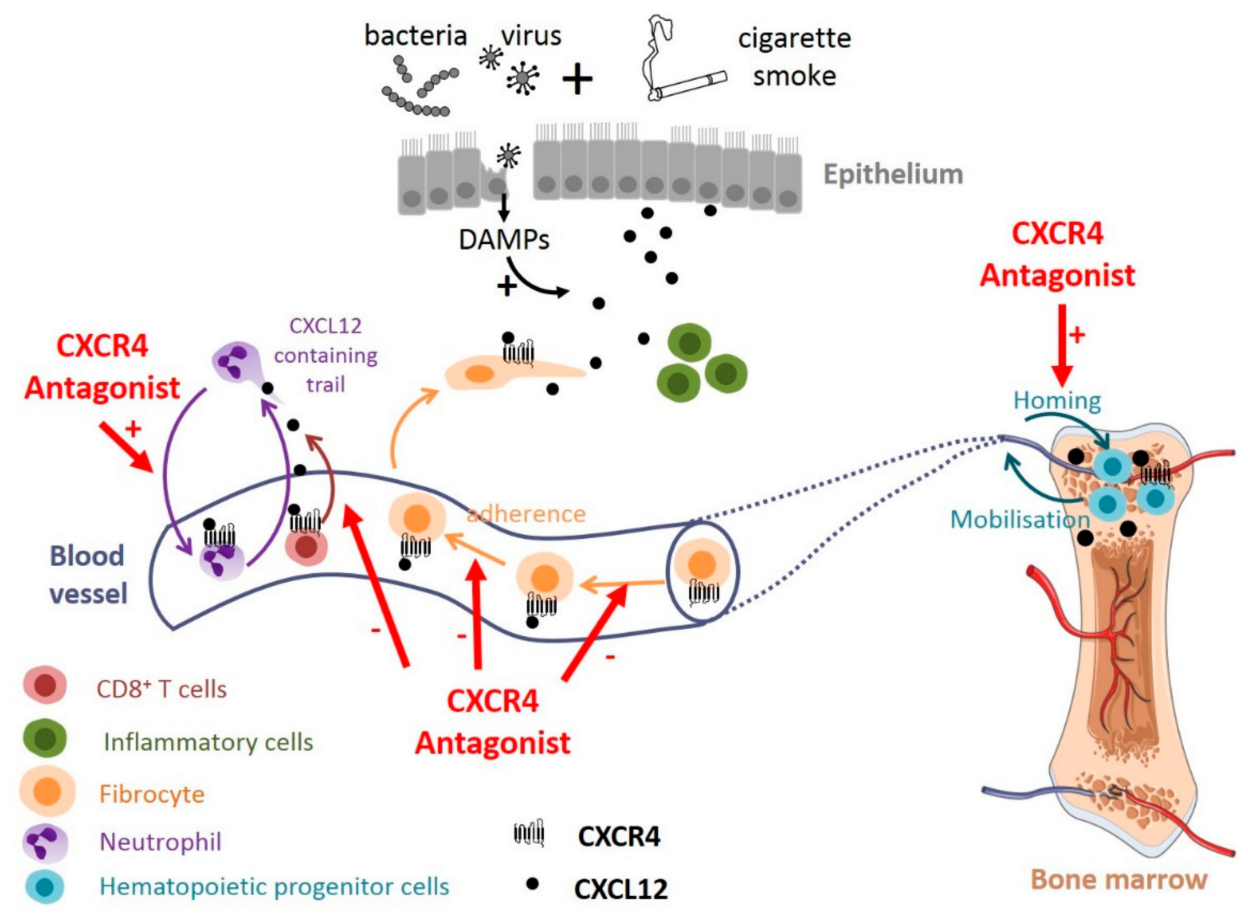

Figure 3. Potential effect of targeting CXCL12/CXCR4 axis in COPD. CXCR4 antagonists might act at various levels in COPD: they could promote neutrophil demargination from the lungs and inhibit T-cells and fibrocytes recruitment into bronchial tissue. CXCR4 antagonists may also contribute to maintaining the pool of hematopoeitic progenitor cells in the bone marrow, available for tissue repair. DAMPs: damage-associated molecular patterns.

Plerixafor also significantly reduced the in vitro plasma-induced migration of fibrocytes purified from the blood of exacerbating COPD patients [76], suggesting that the CXCL12-CXCR4 axis could participate to the recruitment of fibrocytes to the lungs during COPD exacerbations [130]. Antagonizing CXCR4 may therefore reduce the tissular content of fibrocyte-derived fibroblasts and myofibroblasts and subsequent fibrosis, as shown in other clinical settings such as idiopathic pulmonary fibrosis [50] (Figure 3). We can speculate that this type of treatment could interfere not only with fibrocyte migration but also with their adherence to vessels, as CXCR4 activation has been shown to enhance $\beta 1$ integrin function in melanoma cells, resulting in increased adhesion to endothelial cells [165].

In mice, an acute treatment with a high dose of plerixafor has also been shown to promote neutrophil demargination from the lungs [166]. In an influenza-infected mouse model, plerixafor treatment as well as genetic deletion of CXCL12 in neutrophils recapitulates the effect of neutrophil depletion on $\mathrm{CD}^{+} \mathrm{T}$ cell recruitment [132]. Thus, CXCR4 antagonists may also reduce lung inflammation in COPD in which neutrophils and cytotoxic $\mathrm{CD}^{+} \mathrm{T}$ lymphocytes are implicated (Figure 3). Although one could expect that this type of treatment could result in reduced $\mathrm{CD} 8^{+} \mathrm{T}$ cell effector function and could delay the clearance of the virus, it seems that $\mathrm{T}$ cell priming and expansion is not altered in this mouse model [132].

In addition to its effect on the lung and the bone marrow, plerixafor could have a protective effect on the heart: a single injection of plerixafor after myocardial infarction preserves mouse cardiac function by mobilizing the endothelial progenitor cells from bone marrow into peripheral blood [167]. This effect seems to be dependent on MMP-9 up-regulation, mediated by plerixafor-induced VEGF. Similar findings were found in a rat model of myocardial infarction [168]. As cardiovascular diseases are the most frequent comorbidities in COPD patients, it reinforces plerixafor interest as therapeutic option for COPD. Nevertheless, it should be emphasized that most of the data obtained in mice regarding plerixafor effect were obtained using acute treatment with high dose of plerixafor (usually, 
$5 \mathrm{mg} / \mathrm{kg}$ ), and it is therefore possible that chronic exposure with a lower dose in humans may not produce the same effects.

In total, although potential detrimental effects can be expected, antagonizing the CXCL12-CXCR4 axis seems to represent an important opportunity to treat COPD, as recapitulated in the Figure 3.

\section{Conclusions}

The study of chemokines has led to substantial progress in our understanding of COPD pathogenesis and has major implications for potential COPD treatment. The role of chemokines in orchestrating the traffic of immune cells in COPD is now well-recognized, but additional key functions are emerging, albeit their direct contribution to COPD remains to be fully explored. Building novel tools and models to dissect these functions and to assess their roles in COPD remains a major goal for the field. In particular, deciphering the role of chemokines at the gradient level in bone marrow, lymph nodes, peripheral circulation, lungs, and heart will be important to grasp their logic and the potential beneficial and detrimental effects of chemokines or chemokine receptors neutralization. Finally, as COPD is a heterogeneous disease, we strongly believe that selecting subtypes of patients for future clinical trials may improve success in therapeutic development.

Author Contributions: Conception and design: P.H., P.B., and I.D.; writing—original draft preparation: P.H. and I.D.; writing—review and editing: P.H., R.P., P.B., and I.D.; final approval of the manuscript: P.H., R.P., P.B., and I.D.; all authors read and approved the final manuscript.

Funding: This review was supported by a grant from the "Fondation Bordeaux Université", with funding from "Assistance Ventilatoire à Domicile" (AVAD) and "Fédération Girondine de Lutte contre les Maladies Respiratoires" (FGLMR).

Conflicts of Interest: Dr. Berger reports grants from Nycomed; grants from Takeda; grants from Fondation du Souffle-Fonds de dotation Recherche en Santé Respiratoire; grants and personal fees from Novartis; personal fees and non-financial support from Chiesi; grants, personal fees, and non-financial support from Boehringer Ingelheim; personal fees and non-financial support from AstraZeneca; personal fees and non-financial support from Sanofi; personal fees from Menarinni; and personal fees from TEVA outside the submitted work. In addition, Dr. Berger and Dr Dupin have a patent (EP N ${ }^{\circ} 15152886.6$, i.e., New compositions and methods of treating and/or preventing Chronic Obstructive Pulmonary Disease) pending.

\section{Abbreviation}

AIDS Acquired immune deficiency syndrome

AC Adenylate cyclase

BALF Broncho-alveolar lung fluid

BM-MSCs Bone marrow-mesenchymal stem cells

CC16 Club cell-16

CDK9 Cyclin-dependent kinase 9

COPD Chronic obstructive pulmonary disease

CS Cigarette smoke

CSE Cigarette smoke extract

CT Computed tomography

DAMPs Damage-associated molecular patterns

DPPIV Dipeptidyl peptidase-4

ECLIPSE Evaluation of COPD Longitudinally to Identify Predictive Surrogate End-points

ECM Extracellular matrix

EPCs $\quad$ Endothelial progenitor cells

FDA Food and drug administration

FEV1 Forced expiratory volume in one second

FEV1/FVC Forced expiratory volume in one second/forced volume vital capacity

FLAME EFfect of Indacaterol Glycopyronium Vs Fluticasone Salmeterol on COPD Exacerbations

GAGs Glycosaminoglycans 


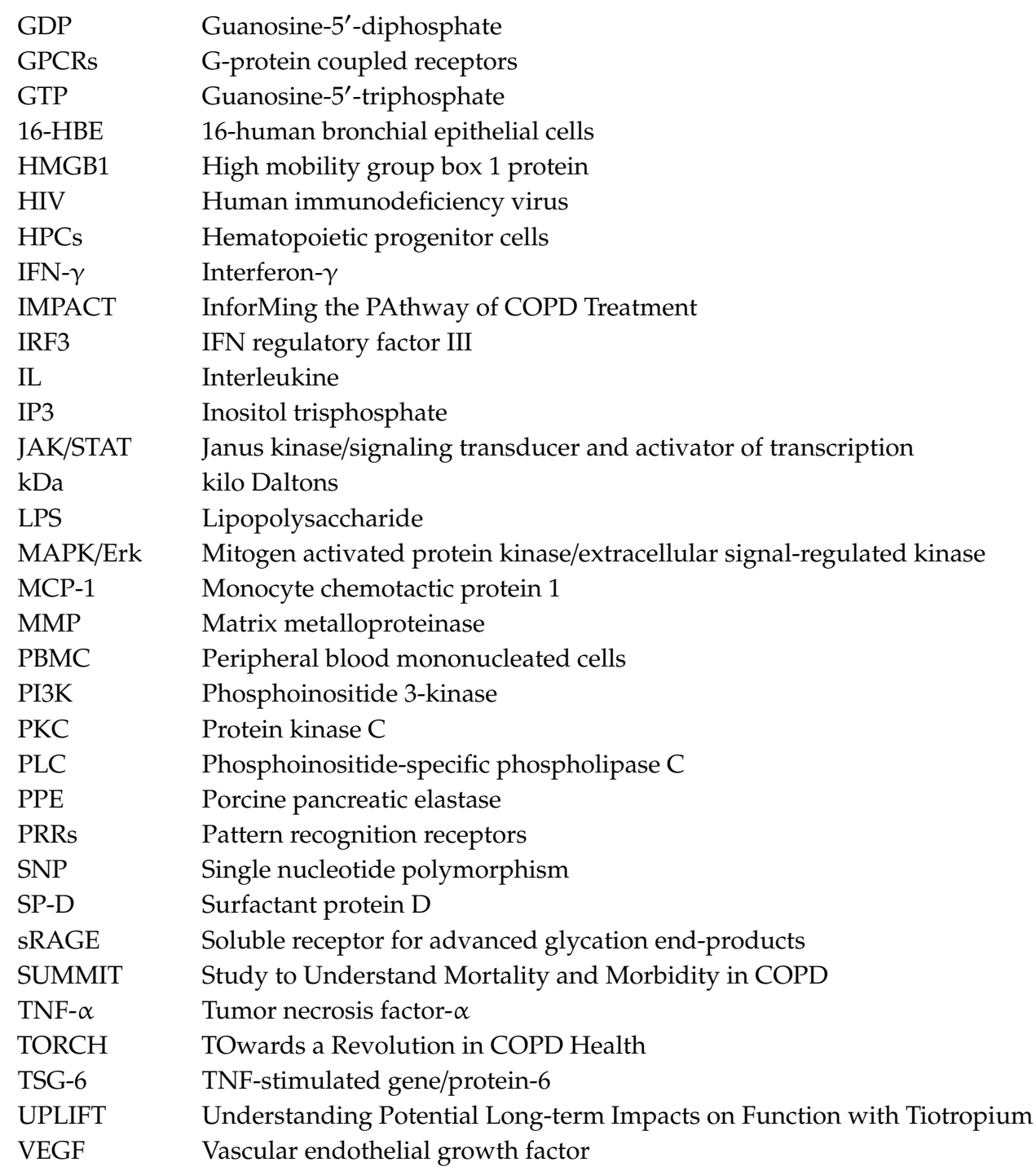

\section{References}

1. Lozano, R.; Naghavi, M.; Foreman, K.; Lim, S.; Shibuya, K.; Aboyans, V.; Abraham, J.; Adair, T.; Aggarwal, R.; Ahn, S.Y.; et al. Global and regional mortality from 235 causes of death for 20 age groups in 1990 and 2010: A systematic analysis for the Global Burden of Disease Study 2010. Lancet Lond. Engl. 2012, 380, 2095-2128. [CrossRef]

2. GBD 2016 Disease and Injury Incidence and Prevalence Collaborators. Global, regional, and national incidence, prevalence, and years lived with disability for 328 diseases and injuries for 195 countries, 1990-2016: A systematic analysis for the Global Burden of Disease Study 2016. Lancet Lond. Engl. 2017, 390, 1211-1259. [CrossRef]

3. Terzikhan, N.; Verhamme, K.M.C.; Hofman, A.; Stricker, B.H.; Brusselle, G.G.; Lahousse, L. Prevalence and incidence of COPD in smokers and non-smokers: The Rotterdam Study. Eur. J. Epidemiol. 2016, 31, 785-792. [CrossRef] [PubMed]

4. Stoller, J.K.; Aboussouan, L.S. Alpha1-antitrypsin deficiency. Lancet Lond. Engl. 2005, 365, $2225-2236$. [CrossRef]

5. Tashkin, D.P.; Altose, M.D.; Bleecker, E.R.; Connett, J.E.; Kanner, R.E.; Lee, W.W.; Wise, R. The lung health study: Airway responsiveness to inhaled methacholine in smokers with mild to moderate airflow limitation. The Lung Health Study Research Group. Am. Rev. Respir. Dis. 1992, 145, 301-310. [CrossRef] [PubMed] 
6. Stern, D.A.; Morgan, W.J.; Wright, A.L.; Guerra, S.; Martinez, F.D. Poor airway function in early infancy and lung function by age 22 years: A non-selective longitudinal cohort study. Lancet Lond. Engl. 2007, 370, 758-764. [CrossRef]

7. Lange, P.; Celli, B.; Agustí, A.; Boje Jensen, G.; Divo, M.; Faner, R.; Guerra, S.; Marott, J.L.; Martinez, F.D.; Martinez-Camblor, P.; et al. Lung-Function Trajectories Leading to Chronic Obstructive Pulmonary Disease. N. Engl. J. Med. 2015, 373, 111-122. [CrossRef] [PubMed]

8. Ko, F.W.; Chan, K.P.; Hui, D.S.; Goddard, J.R.; Shaw, J.G.; Reid, D.W.; Yang, I.A. Acute exacerbation of COPD. Respirol. Carlton VIC 2016, 21, 1152-1165. [CrossRef] [PubMed]

9. Wedzicha, J.A.; Brill, S.E.; Allinson, J.P.; Donaldson, G.C. Mechanisms and impact of the frequent exacerbator phenotype in chronic obstructive pulmonary disease. BMC Med. 2013, 11, 181. [CrossRef]

10. Calverley, P.M.A.; Anderson, J.A.; Celli, B.; Ferguson, G.T.; Jenkins, C.; Jones, P.W.; Yates, J.C.; Vestbo, J. TORCH investigators Salmeterol and fluticasone propionate and survival in chronic obstructive pulmonary disease. N. Engl. J. Med. 2007, 356, 775-789. [CrossRef]

11. Tashkin, D.P.; Celli, B.; Senn, S.; Burkhart, D.; Kesten, S.; Menjoge, S.; Decramer, M. UPLIFT Study Investigators A 4-year trial of tiotropium in chronic obstructive pulmonary disease. N. Engl. J. Med. 2008, 359, 1543-1554. [CrossRef] [PubMed]

12. Vestbo, J.; Anderson, J.A.; Brook, R.D.; Calverley, P.M.A.; Celli, B.R.; Crim, C.; Martinez, F.; Yates, J.; Newby, D.E. SUMMIT Investigators Fluticasone furoate and vilanterol and survival in chronic obstructive pulmonary disease with heightened cardiovascular risk (SUMMIT): A double-blind randomised controlled trial. Lancet Lond. Engl. 2016, 387, 1817-1826. [CrossRef]

13. Wedzicha, J.A.; Banerji, D.; Chapman, K.R.; Vestbo, J.; Roche, N.; Ayers, R.T.; Thach, C.; Fogel, R.; Patalano, F.; Vogelmeier, C.F.; et al. Indacaterol-Glycopyrronium versus Salmeterol-Fluticasone for COPD. N. Engl. J. Med. 2016, 374, 2222-2234. [CrossRef] [PubMed]

14. Lipson, D.A.; Barnhart, F.; Brealey, N.; Brooks, J.; Criner, G.J.; Day, N.C.; Dransfield, M.T.; Halpin, D.M.G.; Han, M.K.; Jones, C.E.; et al. Once-Daily Single-Inhaler Triple versus Dual Therapy in Patients with COPD. N. Engl. J. Med. 2018, 378, 1671-1680. [CrossRef] [PubMed]

15. Barnes, P.J.; Shapiro, S.D.; Pauwels, R.A. Chronic obstructive pulmonary disease: Molecular and cellular mechanisms. Eur. Respir. J. 2003, 22, 672-688. [CrossRef]

16. Dupin, I.; Contin-Bordes, C.; Berger, P. Fibrocytes in Asthma and Chronic Obstructive Pulmonary Disease: Variations on the Same Theme. Am. J. Respir. Cell Mol. Biol. 2018, 58, 288-298. [CrossRef]

17. Baggiolini, M. Chemokines and leukocyte traffic. Nature 1998, 392, 565-568. [CrossRef]

18. Mackay, C.R. Chemokines: immunology's high impact factors. Nat. Immunol. 2001, 2, 95-101. [CrossRef]

19. Youn, B.S.; Mantel, C.; Broxmeyer, H.E. Chemokines, chemokine receptors and hematopoiesis. Immunol. Rev. 2000, 177, 150-174. [CrossRef]

20. Belperio, J.A.; Keane, M.P.; Arenberg, D.A.; Addison, C.L.; Ehlert, J.E.; Burdick, M.D.; Strieter, R.M. CXC chemokines in angiogenesis. J. Leukoc. Biol. 2000, 68, 1-8.

21. Müller, A.; Homey, B.; Soto, H.; Ge, N.; Catron, D.; Buchanan, M.E.; McClanahan, T.; Murphy, E.; Yuan, W.; Wagner, S.N.; et al. Involvement of chemokine receptors in breast cancer metastasis. Nature 2001, 410, 50-56. [CrossRef] [PubMed]

22. Kinter, A.; Arthos, J.; Cicala, C.; Fauci, A.S. Chemokines, cytokines and HIV: A complex network of interactions that influence HIV pathogenesis. Immunol. Rev. 2000, 177, 88-98. [CrossRef] [PubMed]

23. Koenen, R.R.; Weber, C. Therapeutic targeting of chemokine interactions in atherosclerosis. Nat. Rev. Drug Discov. 2010, 9, 141-153. [CrossRef] [PubMed]

24. Zlotnik, A.; Yoshie, O. Chemokines: A new classification system and their role in immunity. Immunity 2000, 12, 121-127. [CrossRef]

25. Miller, M.C.; Mayo, K.H. Chemokines from a Structural Perspective. Int. J. Mol. Sci. 2017, 18, 2088. [CrossRef] [PubMed]

26. Allen, S.J.; Crown, S.E.; Handel, T.M. Chemokine: Receptor structure, interactions, and antagonism. Annu. Rev. Immunol. 2007, 25, 787-820. [CrossRef] [PubMed]

27. Nibbs, R.J.B.; Graham, G.J. Immune regulation by atypical chemokine receptors. Nat. Rev. Immunol. 2013, 13, 815-829. [CrossRef] 
28. Strieter, R.M.; Polverini, P.J.; Kunkel, S.L.; Arenberg, D.A.; Burdick, M.D.; Kasper, J.; Dzuiba, J.; Van Damme, J.; Walz, A.; Marriott, D. The functional role of the ELR motif in CXC chemokine-mediated angiogenesis. J. Biol. Chem. 1995, 270, 27348-27357. [CrossRef]

29. Ludeman, J.P.; Stone, M.J. The structural role of receptor tyrosine sulfation in chemokine recognition. Br. J. Pharmacol. 2014, 171, 1167-1179. [CrossRef]

30. Veldkamp, C.T.; Seibert, C.; Peterson, F.C.; De la Cruz, N.B.; Haugner, J.C.; Basnet, H.; Sakmar, T.P.; Volkman, B.F. Structural basis of CXCR4 sulfotyrosine recognition by the chemokine SDF-1/CXCL12. Sci. Signal. 2008, 1, ra4. [CrossRef]

31. Legler, D.F.; Thelen, M. New insights in chemokine signaling. F1000Research 2018, 7, 95. [CrossRef] [PubMed]

32. Thelen, M. Dancing to the tune of chemokines. Nat. Immunol. 2001, 2, 129-134. [CrossRef]

33. Colamussi, M.L.; Secchiero, P.; Gonelli, A.; Marchisio, M.; Zauli, G.; Capitani, S. Stromal derived factor-1 alpha (SDF-1 alpha) induces CD4+ T cell apoptosis via the functional up-regulation of the Fas (CD95)/Fas ligand (CD95L) pathway. J. Leukoc. Biol. 2001, 69, 263-270. [PubMed]

34. Drury, L.J.; Wendt, M.K.; Dwinell, M.B. CXCL12 chemokine expression and secretion regulates colorectal carcinoma cell anoikis through Bim-mediated intrinsic apoptosis. PLoS ONE 2010, 5, e12895. [CrossRef] [PubMed]

35. Kremer, K.N.; Peterson, K.L.; Schneider, P.A.; Meng, X.W.; Dai, H.; Hess, A.D.; Smith, B.D.; Rodriguez-Ramirez, C.; Karp, J.E.; Kaufmann, S.H.; et al. CXCR4 chemokine receptor signaling induces apoptosis in acute myeloid leukemia cells via regulation of the Bcl-2 family members Bcl-XL, Noxa, and Bak. J. Biol. Chem. 2013, 288, 22899-22914. [CrossRef] [PubMed]

36. Ravi, A.K.; Plumb, J.; Gaskell, R.; Mason, S.; Broome, C.S.; Booth, G.; Catley, M.; Vestbo, J.; Singh, D. COPD monocytes demonstrate impaired migratory ability. Respir. Res. 2017, 18, 90. [CrossRef]

37. Kufareva, I.; Gustavsson, M.; Zheng, Y.; Stephens, B.S.; Handel, T.M. What Do Structures Tell Us About Chemokine Receptor Function and Antagonism? Annu. Rev. Biophys. 2017, 46, 175-198. [CrossRef]

38. Arimont, M.; Sun, S.-L.; Leurs, R.; Smit, M.; de Esch, I.J.P.; de Graaf, C. Structural Analysis of Chemokine Receptor-Ligand Interactions. J. Med. Chem. 2017, 60, 4735-4779. [CrossRef]

39. Proudfoot, A.E.I.; Uguccioni, M. Modulation of Chemokine Responses: Synergy and Cooperativity. Front. Immunol. 2016, 7, 183. [CrossRef]

40. Schiraldi, M.; Raucci, A.; Muñoz, L.M.; Livoti, E.; Celona, B.; Venereau, E.; Apuzzo, T.; De Marchis, F.; Pedotti, M.; Bachi, A.; et al. HMGB1 promotes recruitment of inflammatory cells to damaged tissues by forming a complex with CXCL12 and signaling via CXCR4. J. Exp. Med. 2012, 209, 551-563. [CrossRef]

41. Campana, L.; Bosurgi, L.; Bianchi, M.E.; Manfredi, A.A.; Rovere-Querini, P. Requirement of HMGB1 for stromal cell-derived factor-1/CXCL12-dependent migration of macrophages and dendritic cells. J. Leukoc. Biol. 2009, 86, 609-615. [CrossRef] [PubMed]

42. Proudfoot, A.E.I. Chemokines and Glycosaminoglycans. Front. Immunol. 2015, 6, 246. [CrossRef] [PubMed]

43. Drury, L.J.; Ziarek, J.J.; Gravel, S.; Veldkamp, C.T.; Takekoshi, T.; Hwang, S.T.; Heveker, N.; Volkman, B.F.; Dwinell, M.B. Monomeric and dimeric CXCL12 inhibit metastasis through distinct CXCR4 interactions and signaling pathways. Proc. Natl. Acad. Sci. USA 2011, 108, 17655-17660. [CrossRef] [PubMed]

44. Proudfoot, A.E.I.; Handel, T.M.; Johnson, Z.; Lau, E.K.; LiWang, P.; Clark-Lewis, I.; Borlat, F.; Wells, T.N.C.; Kosco-Vilbois, M.H. Glycosaminoglycan binding and oligomerization are essential for the in vivo activity of certain chemokines. Proc. Natl. Acad. Sci. USA 2003, 100, 1885-1890. [CrossRef] [PubMed]

45. Burgstaller, G.; Oehrle, B.; Gerckens, M.; White, E.S.; Schiller, H.B.; Eickelberg, O. The instructive extracellular matrix of the lung: Basic composition and alterations in chronic lung disease. Eur. Respir. J. 2017, 50, 1601805. [CrossRef]

46. Sand, J.M.B.; Knox, A.J.; Lange, P.; Sun, S.; Kristensen, J.H.; Leeming, D.J.; Karsdal, M.A.; Bolton, C.E.; Johnson, S.R. Accelerated extracellular matrix turnover during exacerbations of COPD. Respir. Res. 2015, 16, 69. [CrossRef] [PubMed]

47. Mestas, J.; Hughes, C.C.W. Of Mice and Not Men: Differences between Mouse and Human Immunology. J. Immunol. 2004, 172, 2731-2738. [CrossRef] [PubMed]

48. Du, Y.; Deng, W.; Wang, Z.; Ning, M.; Zhang, W.; Zhou, Y.; Lo, E.H.; Xing, C. Differential subnetwork of chemokines/cytokines in human, mouse, and rat brain cells after oxygen-glucose deprivation. J. Cereb. Blood Flow Metab. 2017, 37, 1425-1434. [CrossRef] 
49. Weber, M.; Hauschild, R.; Schwarz, J.; Moussion, C.; de Vries, I.; Legler, D.F.; Luther, S.A.; Bollenbach, T.; Sixt, M. Interstitial dendritic cell guidance by haptotactic chemokine gradients. Science 2013, 339, 328-332. [CrossRef]

50. Phillips, R.J.; Burdick, M.D.; Hong, K.; Lutz, M.A.; Murray, L.A.; Xue, Y.Y.; Belperio, J.A.; Keane, M.P.; Strieter, R.M. Circulating fibrocytes traffic to the lungs in response to CXCL12 and mediate fibrosis. J. Clin. Investig. 2004, 114, 438-446. [CrossRef]

51. Gangavarapu, P.; Rajagopalan, L.; Kolli, D.; Guerrero-Plata, A.; Garofalo, R.P.; Rajarathnam, K. The monomer-dimer equilibrium and glycosaminoglycan interactions of chemokine CXCL8 regulate tissue-specific neutrophil recruitment. J. Leukoc. Biol. 2012, 91, 259-265. [CrossRef] [PubMed]

52. Tanino, Y.; Coombe, D.R.; Gill, S.E.; Kett, W.C.; Kajikawa, O.; Proudfoot, A.E.I.; Wells, T.N.C.; Parks, W.C.; Wight, T.N.; Martin, T.R.; et al. Kinetics of chemokine-glycosaminoglycan interactions control neutrophil migration into the airspaces of the lungs. J. Immunol. 2010, 184, 2677-2685. [CrossRef] [PubMed]

53. GOLD 1998. Global Initiative for Chronic Obstructive Lung Disease. Global Strategy for the Diagnosis, Management and Prevention of Chronic Obstructive Pulmonary Disease. NIH Publication (Updated 2019). Available online: http://www.goldcopd.org (accessed on 1 April 2019).

54. Pauwels, R.A.; Buist, A.S.; Calverley, P.M.; Jenkins, C.R.; Hurd, S.S. GOLD Scientific Committee Global strategy for the diagnosis, management, and prevention of chronic obstructive pulmonary disease. NHLBI/WHO Global Initiative for Chronic Obstructive Lung Disease (GOLD) Workshop summary. Am. J. Respir. Crit. Care Med. 2001, 163, 1256-1276. [CrossRef] [PubMed]

55. Inui, T.; Watanabe, M.; Nakamoto, K.; Sada, M.; Hirata, A.; Nakamura, M.; Honda, K.; Ogawa, Y.; Takata, S.; Yokoyama, T.; et al. Bronchial epithelial cells produce CXCL1 in response to LPS and TNF $\alpha$ : A potential role in the pathogenesis of COPD. Exp. Lung Res. 2019, 44, 323-331. [CrossRef] [PubMed]

56. Traves, S.L.; Culpitt, S.V.; Russell, R.E.K.; Barnes, P.J.; Donnelly, L.E. Increased levels of the chemokines GROalpha and MCP-1 in sputum samples from patients with COPD. Thorax 2002, 57, 590-595. [CrossRef] [PubMed]

57. Beeh, K.M.; Kornmann, O.; Buhl, R.; Culpitt, S.V.; Giembycz, M.A.; Barnes, P.J. Neutrophil chemotactic activity of sputum from patients with COPD: Role of interleukin 8 and leukotriene B4. Chest 2003, 123, 1240-1247. [CrossRef] [PubMed]

58. Qiu, Y.; Zhu, J.; Bandi, V.; Atmar, R.L.; Hattotuwa, K.; Guntupalli, K.K.; Jeffery, P.K. Biopsy neutrophilia, neutrophil chemokine and receptor gene expression in severe exacerbations of chronic obstructive pulmonary disease. Am. J. Respir. Crit. Care Med. 2003, 168, 968-975. [CrossRef] [PubMed]

59. Stefano, A.D.; Caramori, G.; Gnemmi, I.; Contoli, M.; Bristot, L.; Capelli, A.; Ricciardolo, F.L.M.; Magno, F.; D'Anna, S.E.; Zanini, A.; et al. Association of increased CCL5 and CXCL7 chemokine expression with neutrophil activation in severe stable COPD. Thorax 2009, 64, 968-975. [CrossRef]

60. Keatings, V.M.; Collins, P.D.; Scott, D.M.; Barnes, P.J. Differences in interleukin-8 and tumor necrosis factor-alpha in induced sputum from patients with chronic obstructive pulmonary disease or asthma. Am. J. Respir. Crit. Care Med. 1996, 153, 530-534. [CrossRef]

61. Osei, E.T.; Noordhoek, J.A.; Hackett, T.L.; Spanjer, A.I.R.; Postma, D.S.; Timens, W.; Brandsma, C.-A.; Heijink, I.H. Interleukin-1 $\alpha$ drives the dysfunctional cross-talk of the airway epithelium and lung fibroblasts in COPD. Eur. Respir. J. 2016, 48, 359-369. [CrossRef]

62. Patel, B.S.; Kugel, M.J.; Baehring, G.; Ammit, A.J. Doxofylline does not increase formoterol-induced cAMP nor MKP-1 expression in ASM cells resulting in lack of anti-inflammatory effect. Pulm. Pharmacol. Ther. 2017, 45, 34-39. [CrossRef] [PubMed]

63. Ikari, J.; Nelson, A.J.; Obaid, J.; Giron-Martinez, A.; Ikari, K.; Makino, F.; Iwasawa, S.; Gunji, Y.; Farid, M.; Wang, X.; et al. Reduced microRNA-503 expression augments lung fibroblast VEGF production in chronic obstructive pulmonary disease. PLoS ONE 2017, 12, e0184039. [CrossRef] [PubMed]

64. De Llano, L.P.; Cosío, B.G.; Iglesias, A.; de Las Cuevas, N.; Soler-Cataluña, J.J.; Izquierdo, J.L.; López-Campos, J.L.; Calero, C.; Plaza, V.; Miravitlles, M.; et al. Mixed Th2 and non-Th2 inflammatory pattern in the asthma-COPD overlap: A network approach. Int. J. Chronic Obstruct. Pulm. Dis. 2018, 13, 591-601. [CrossRef] [PubMed]

65. De Boer, W.I.; Sont, J.K.; van Schadewijk, A.; Stolk, J.; van Krieken, J.H.; Hiemstra, P.S. Monocyte chemoattractant protein 1 , interleukin 8 , and chronic airways inflammation in COPD. J. Pathol. 2000, 190, 619-626. [CrossRef] 
66. Belchamber, K.B.R.; Donnelly, L.E. Macrophage Dysfunction in Respiratory Disease. Results Probl. Cell Differ. 2017, 62, 299-313. [PubMed]

67. Huang, Z.-W.; Lien, G.-S.; Lin, C.-H.; Jiang, C.-P.; Chen, B.-C. p300 and C/EBP $\beta$-regulated IKK $\beta$ expression are involved in thrombin-induced IL-8/CXCL8 expression in human lung epithelial cells. Pharmacol. Res. 2017, 121, 33-41. [CrossRef] [PubMed]

68. Costa, C.; Rufino, R.; Traves, S.L.; Lapa E Silva, J.R.; Barnes, P.J.; Donnelly, L.E. CXCR3 and CCR5 chemokines in induced sputum from patients with COPD. Chest 2008, 133, 26-33. [CrossRef]

69. Kelsen, S.G.; Aksoy, M.O.; Georgy, M.; Hershman, R.; Ji, R.; Li, X.; Hurford, M.; Solomides, C.; Chatila, W.; Kim, V. Lymphoid Follicle Cells in Chronic Obstructive Pulmonary Disease Overexpress the Chemokine Receptor CXCR3. Am. J. Respir. Crit. Care Med. 2009, 179, 799-805. [CrossRef]

70. Tura-Ceide, O.; Lobo, B.; Paul, T.; Puig-Pey, R.; Coll-Bonfill, N.; García-Lucio, J.; Smolders, V.; Blanco, I.; Barberà, J.A.; Peinado, V.I. Cigarette smoke challenges bone marrow mesenchymal stem cell capacities in guinea pig. Respir. Res. 2017, 18,50. [CrossRef]

71. Hardaker, E.L.; Bacon, A.M.; Carlson, K.; Roshak, A.K.; Foley, J.J.; Schmidt, D.B.; Buckley, P.T.; Comegys, M.; Panettieri, R.A.; Sarau, H.M.; et al. Regulation of TNF-alpha- and IFN-gamma-induced CXCL10 expression: Participation of the airway smooth muscle in the pulmonary inflammatory response in chronic obstructive pulmonary disease. FASEB J. Off. Publ. Fed. Am. Soc. Exp. Biol. 2004, 18, 191-193.

72. Saetta, M.; Mariani, M.; Panina-Bordignon, P.; Turato, G.; Buonsanti, C.; Baraldo, S.; Bellettato, C.M.; Papi, A.; Corbetta, L.; Zuin, R.; et al. Increased expression of the chemokine receptor CXCR3 and its ligand CXCL10 in peripheral airways of smokers with chronic obstructive pulmonary disease. Am. J. Respir. Crit. Care Med. 2002, 165, 1404-1409. [CrossRef] [PubMed]

73. Quint, J.K.; Donaldson, G.C.; Goldring, J.J.P.; Baghai-Ravary, R.; Hurst, J.R.; Wedzicha, J.A. Serum IP-10 as a biomarker of human rhinovirus infection at exacerbation of COPD. Chest 2010, 137, 812-822. [CrossRef] [PubMed]

74. Barwinska, D.; Oueini, H.; Poirier, C.; Albrecht, M.E.; Bogatcheva, N.V.; Justice, M.J.; Saliba, J.; Schweitzer, K.S.; Broxmeyer, H.E.; March, K.L.; et al. AMD3100 ameliorates cigarette smoke-induced emphysema-like manifestations in mice. Am. J. Physiol. Lung Cell. Mol. Physiol. 2018, 315, L382-L386. [CrossRef]

75. Karagiannis, K.; Proklou, A.; Tsitoura, E.; Lasithiotaki, I.; Kalpadaki, C.; Moraitaki, D.; Sperelakis, I.; Kontakis, G.; Antoniou, K.M.; Tzanakis, N. Impaired mRNA Expression of the Migration Related Chemokine Receptor CXCR4 in Mesenchymal Stem Cells of COPD Patients. Int. J. Inflamm. 2017, 2017, 6089425. [CrossRef]

76. Dupin, I.; Allard, B.; Ozier, A.; Maurat, E.; Ousova, O.; Delbrel, E.; Trian, T.; Bui, H.-N.; Dromer, C.; Guisset, O.; et al. Blood fibrocytes are recruited during acute exacerbations of chronic obstructive pulmonary disease through a CXCR4-dependent pathway. J. Allergy Clin. Immunol. 2016, 137, 1036.e7-1042.e7. [CrossRef] [PubMed]

77. Vishweswaraiah, S.; Thimraj, T.A.; George, L.; Krishnarao, C.S.; Lokesh, K.S.; Siddaiah, J.B.; Larsson, K.; Upadhyay, S.; Palmberg, L.; Anand, M.P.; et al. Putative Systemic Biomarkers of Biomass Smoke-Induced Chronic Obstructive Pulmonary Disease among Women in a Rural South Indian Population. Dis. Mark. 2018, 2018, 4949175. [CrossRef] [PubMed]

78. Marques, P.; Collado, A.; Escudero, P.; Rius, C.; González, C.; Servera, E.; Piqueras, L.; Sanz, M.-J. Cigarette Smoke Increases Endothelial CXCL16-Leukocyte CXCR6 Adhesion In Vitro and In Vivo. Potential Consequences in Chronic Obstructive Pulmonary Disease. Front. Immunol. 2017, 8, 1766. [CrossRef]

79. Jing, H.; Liu, L.; Zhou, J.; Yao, H. Inhibition of C-X-C Motif Chemokine 10 (CXCL10) Protects Mice from Cigarette Smoke-Induced Chronic Obstructive Pulmonary Disease. Med. Sci. Monit. Int. Med. J. Exp. Clin. Res. 2018, 24, 5748-5753. [CrossRef]

80. Di Stefano, A.; Coccini, T.; Roda, E.; Signorini, C.; Balbi, B.; Brunetti, G.; Ceriana, P. Blood MCP-1 levels are increased in chronic obstructive pulmonary disease patients with prevalent emphysema. Int. J. Chronic Obstruct. Pulm. Dis. 2018, 13, 1691-1700. [CrossRef]

81. Ravi, A.K.; Khurana, S.; Lemon, J.; Plumb, J.; Booth, G.; Healy, L.; Catley, M.; Vestbo, J.; Singh, D. Increased levels of soluble interleukin-6 receptor and CCL3 in COPD sputum. Respir. Res. 2014, 15, 103. [CrossRef]

82. Bradford, E.; Jacobson, S.; Varasteh, J.; Comellas, A.P.; Woodruff, P.; O’Neal, W.; DeMeo, D.L.; Li, X.; Kim, V.; Cho, M.; et al. The value of blood cytokines and chemokines in assessing COPD. Respir. Res. 2017, 18, 180. [CrossRef] [PubMed] 
83. D'Armiento, J.M.; Scharf, S.M.; Roth, M.D.; Connett, J.E.; Ghio, A.; Sternberg, D.; Goldin, J.G.; Louis, T.A.; Mao, J.T.; O'Connor, G.T.; et al. Eosinophil and T cell markers predict functional decline in COPD patients. Respir. Res. 2009, 10, 113. [CrossRef] [PubMed]

84. Bocchino, V.; Bertorelli, G.; Bertrand, C.P.; Ponath, P.D.; Newman, W.; Franco, C.; Marruchella, A.; Merlini, S.; Del Donno, M.; Zhuo, X.; et al. Eotaxin and CCR3 are up-regulated in exacerbations of chronic bronchitis. Allergy 2002, 57, 17-22. [PubMed]

85. Miller, M.; Ramsdell, J.; Friedman, P.J.; Cho, J.Y.; Renvall, M.; Broide, D.H. Computed tomographic scan-diagnosed chronic obstructive pulmonary disease-emphysema: Eotaxin-1 is associated with bronchodilator response and extent of emphysema. J. Allergy Clin. Immunol. 2007, 120, 1118-1125. [CrossRef] [PubMed]

86. Sin, D.D.; Miller, B.E.; Duvoix, A.; Man, S.F.P.; Zhang, X.; Silverman, E.K.; Connett, J.E.; Anthonisen, N.A.; Wise, R.A.; Tashkin, D.; et al. Serum PARC/CCL-18 concentrations and health outcomes in chronic obstructive pulmonary disease. Am. J. Respir. Crit. Care Med. 2011, 183, 1187-1192. [CrossRef] [PubMed]

87. Muñoz-Esquerre, M.; Aliagas, E.; López-Sánchez, M.; Escobar, I.; Huertas, D.; Penín, R.; Dorca, J.; Santos, S. Vascular disease in COPD: Systemic and pulmonary expression of PARC (Pulmonary and Activation-Regulated Chemokine). PLoS ONE 2017, 12, e0177218. [CrossRef] [PubMed]

88. Demedts, I.K.; Bracke, K.R.; Van Pottelberge, G.; Testelmans, D.; Verleden, G.M.; Vermassen, F.E.; Joos, G.F.; Brusselle, G.G. Accumulation of dendritic cells and increased CCL20 levels in the airways of patients with chronic obstructive pulmonary disease. Am. J. Respir. Crit. Care Med. 2007, 175, 998-1005. [CrossRef]

89. Hao, W.; Li, M.; Zhang, C.; Zhang, Y.; Xue, Y. High Serum Fractalkine/CX3CL1 in Patients with Chronic Obstructive Pulmonary Disease: Relationship with Emphysema Severity and Frequent Exacerbation. Lung 2019, 197, 29-35. [CrossRef]

90. Barnes, P.J. The Cytokine Network in Chronic Obstructive Pulmonary Disease. Am. J. Respir. Cell Mol. Biol. 2009, 41, 631-638. [CrossRef]

91. Kim, V.; Cornwell, W.D.; Oros, M.; Durra, H.; Criner, G.J.; Rogers, T.J. Plasma Chemokine signature correlates with lung goblet cell hyperplasia in smokers with and without chronic obstructive pulmonary disease. $B M C$ Pulm. Med. 2015, 15, 111. [CrossRef]

92. Ying, S.; O'Connor, B.; Ratoff, J.; Meng, Q.; Fang, C.; Cousins, D.; Zhang, G.; Gu, S.; Gao, Z.; Shamji, B.; et al. Expression and cellular provenance of thymic stromal lymphopoietin and chemokines in patients with severe asthma and chronic obstructive pulmonary disease. J. Immunol. 2008, 181, 2790-2798. [CrossRef] [PubMed]

93. Tanino, M.; Betsuyaku, T.; Takeyabu, K.; Tanino, Y.; Yamaguchi, E.; Miyamoto, K.; Nishimura, M. Increased levels of interleukin-8 in BAL fluid from smokers susceptible to pulmonary emphysema. Thorax 2002, 57, 405-411. [CrossRef] [PubMed]

94. Yamamoto, C.; Yoneda, T.; Yoshikawa, M.; Fu, A.; Tokuyama, T.; Tsukaguchi, K.; Narita, N. Airway inflammation in COPD assessed by sputum levels of interleukin-8. Chest 1997, 112, 505-510. [CrossRef] [PubMed]

95. Woolhouse, I.S.; Bayley, D.L.; Stockley, R.A. Sputum chemotactic activity in chronic obstructive pulmonary disease: Effect of alpha(1)-antitrypsin deficiency and the role of leukotriene $\mathrm{B}(4)$ and interleukin 8 . Thorax 2002, 57, 709-714. [CrossRef] [PubMed]

96. Peveri, P.; Walz, A.; Dewald, B.; Baggiolini, M. A novel neutrophil-activating factor produced by human mononuclear phagocytes. J. Exp. Med. 1988, 167, 1547-1559. [CrossRef] [PubMed]

97. Zarcone, M.C.; Duistermaat, E.; Alblas, M.J.; van Schadewijk, A.; Ninaber, D.K.; Clarijs, V.; Moerman, M.M.; Vaessen, D.; Hiemstra, P.S.; Kooter, I.M. Effect of diesel exhaust generated by a city bus engine on stress responses and innate immunity in primary bronchial epithelial cell cultures. Toxicol. In Vitro Int. J. Publ. Assoc. BIBRA 2018, 48, 221-231. [CrossRef] [PubMed]

98. Liu, L.; Wan, C.; Zhang, W.; Guan, L.; Tian, G.; Zhang, F.; Ding, W. MiR-146a regulates PM1-induced inflammation via NF-кB signaling pathway in BEAS-2B cells. Environ. Toxicol. 2018, 33, 743-751. [CrossRef]

99. Sangiorgi, C.; Vallese, D.; Gnemmi, I.; Bucchieri, F.; Balbi, B.; Brun, P.; Leone, A.; Giordano, A.; Conway de Macario, E.; Macario, A.J.; et al. HSP60 activity on human bronchial epithelial cells. Int. J. Immunopathol. Pharmacol. 2017, 30, 333-340. [CrossRef] 
100. Reutershan, J.; Morris, M.A.; Burcin, T.L.; Smith, D.F.; Chang, D.; Saprito, M.S.; Ley, K. Critical role of endothelial CXCR2 in LPS-induced neutrophil migration into the lung. J. Clin. Investig. 2006, 116, 695-702. [CrossRef]

101. Jiang, J.-X.; Zhang, S.-J.; Shen, H.-J.; Guan, Y.; Liu, Q.; Zhao, W.; Jia, Y.-L.; Shen, J.; Yan, X.-F.; Xie, Q.-M. Rac1 signaling regulates cigarette smoke-induced inflammation in the lung via the Erk1/2 MAPK and STAT3 pathways. Biochim. Biophys. Acta Mol. Basis Dis. 2017, 1863, 1778-1788. [CrossRef]

102. Aaron, S.D.; Angel, J.B.; Lunau, M.; Wright, K.; Fex, C.; Le Saux, N.; Dales, R.E. Granulocyte inflammatory markers and airway infection during acute exacerbation of chronic obstructive pulmonary disease. Am. J. Respir. Crit. Care Med. 2001, 163, 349-355. [CrossRef] [PubMed]

103. Mikami, M.; Llewellyn-Jones, C.G.; Bayley, D.; Hill, S.L.; Stockley, R.A. The chemotactic activity of sputum from patients with bronchiectasis. Am. J. Respir. Crit. Care Med. 1998, 157, 723-728. [CrossRef] [PubMed]

104. Zhang, J.; Bai, C. The Significance of Serum Interleukin-8 in Acute Exacerbations of Chronic Obstructive Pulmonary Disease. Tanaffos 2018, 17, 13-21. [PubMed]

105. Han, M.K.; Quibrera, P.M.; Carretta, E.E.; Barr, R.G.; Bleecker, E.R.; Bowler, R.P.; Cooper, C.B.; Comellas, A.; Couper, D.J.; Curtis, J.L.; et al. Frequency of exacerbations in patients with chronic obstructive pulmonary disease: An analysis of the SPIROMICS cohort. Lancet Respir. Med. 2017, 5, 619-626. [CrossRef]

106. Soler, N.; Ewig, S.; Torres, A.; Filella, X.; Gonzalez, J.; Zaubet, A. Airway inflammation and bronchial microbial patterns in patients with stable chronic obstructive pulmonary disease. Eur. Respir. J. 1999, 14, 1015-1022. [CrossRef] [PubMed]

107. Nakajima, M.; Kawaguchi, M.; Matsuyama, M.; Ota, K.; Fujita, J.; Matsukura, S.; Huang, S.-K.; Morishima, Y.; Ishii, Y.; Satoh, H.; et al. Transcription Elongation Factor P-TEFb Is Involved in IL-17F Signaling in Airway Smooth Muscle Cells. Int. Arch. Allergy Immunol. 2018, 176, 83-90. [CrossRef]

108. Donnelly, L.E.; Barnes, P.J. Chemokine receptors as therapeutic targets in chronic obstructive pulmonary disease. Trends Pharmacol. Sci. 2006, 27, 546-553. [CrossRef]

109. Pechkovsky, D.V.; Goldmann, T.; Ludwig, C.; Prasse, A.; Vollmer, E.; Müller-Quernheim, J.; Zissel, G. CCR2 and CXCR3 agonistic chemokines are differently expressed and regulated in human alveolar epithelial cells type II. Respir. Res. 2005, 6, 75. [CrossRef]

110. Sauty, A.; Dziejman, M.; Taha, R.A.; Iarossi, A.S.; Neote, K.; Garcia-Zepeda, E.A.; Hamid, Q.; Luster, A.D. The T cell-specific CXC chemokines IP-10, Mig, and I-TAC are expressed by activated human bronchial epithelial cells. J. Immunol. 1999, 162, 3549-3558.

111. Groom, J.R.; Luster, A.D. CXCR3 ligands: Redundant, collaborative and antagonistic functions. Immunol. Cell Biol. 2011, 89, 207-215. [CrossRef]

112. Barnes, P.J. Cellular and molecular mechanisms of asthma and COPD. Clin. Sci. Lond. Engl. 2017, 131, 1541-1558. [CrossRef]

113. Costa, C.; Traves, S.L.; Tudhope, S.J.; Fenwick, P.S.; Belchamber, K.B.R.; Russell, R.E.K.; Barnes, P.J.; Donnelly, L.E. Enhanced monocyte migration to CXCR3 and CCR5 chemokines in COPD. Eur. Respir. J. 2016, 47, 1093-1102. [CrossRef] [PubMed]

114. Cole, K.E.; Strick, C.A.; Paradis, T.J.; Ogborne, K.T.; Loetscher, M.; Gladue, R.P.; Lin, W.; Boyd, J.G.; Moser, B.; Wood, D.E.; et al. Interferon-inducible T cell alpha chemoattractant (I-TAC): A novel non-ELR CXC chemokine with potent activity on activated T cells through selective high affinity binding to CXCR3. J. Exp. Med. 1998, 187, 2009-2021. [CrossRef] [PubMed]

115. Grumelli, S.; Corry, D.B.; Song, L.-Z.; Song, L.; Green, L.; Huh, J.; Hacken, J.; Espada, R.; Bag, R.; Lewis, D.E.; et al. An immune basis for lung parenchymal destruction in chronic obstructive pulmonary disease and emphysema. PLoS Med. 2004, 1, e8. [CrossRef] [PubMed]

116. Cosio, M.G.; Majo, J.; Cosio, M.G. Inflammation of the airways and lung parenchyma in COPD: Role of T cells. Chest 2002, 121, 160S-165S. [CrossRef] [PubMed]

117. Porter, J.C.; Falzon, M.; Hall, A. Polarized localization of epithelial CXCL11 in chronic obstructive pulmonary disease and mechanisms of T cell egression. J. Immunol. 2008, 180, 1866-1877. [CrossRef] [PubMed]

118. Warwick, G.; Thomas, P.S.; Yates, D.H. Non-invasive biomarkers in exacerbations of obstructive lung disease. Respirol. Carlton VIC 2013, 18, 874-884. [CrossRef]

119. Bafadhel, M.; McKenna, S.; Terry, S.; Mistry, V.; Reid, C.; Haldar, P.; McCormick, M.; Haldar, K.; Kebadze, T.; Duvoix, A.; et al. Acute exacerbations of chronic obstructive pulmonary disease: Identification of biologic clusters and their biomarkers. Am. J. Respir. Crit. Care Med. 2011, 184, 662-671. [CrossRef] [PubMed] 
120. Clarke, D.L.; Clifford, R.L.; Jindarat, S.; Proud, D.; Pang, L.; Belvisi, M.; Knox, A.J. TNF $\alpha$ and IFN $\gamma$ synergistically enhance transcriptional activation of CXCL10 in human airway smooth muscle cells via STAT-1, NF- $\mathrm{BB}$, and the transcriptional coactivator CREB-binding protein. J. Biol. Chem. 2010, 285, 29101-29110. [CrossRef] [PubMed]

121. Cole, A.M.; Ganz, T.; Liese, A.M.; Burdick, M.D.; Liu, L.; Strieter, R.M. Cutting edge: IFN-inducible ELRCXC chemokines display defensin-like antimicrobial activity. J. Immunol. 2001, 167, 623-627. [CrossRef] [PubMed]

122. Bai, J.; Song, H.; Cai, C.; Zhang, M.; Xu, S.; Tan, J. The association of monocyte chemotactic protein-1 and CC chemokine receptor 2 gene variants with chronic obstructive pulmonary disease. DNA Cell Biol. 2012, 31, 1058-1063. [CrossRef] [PubMed]

123. Zheng, J.; Shi, Y.; Xiong, L.; Zhang, W.; Li, Y.; Gibson, P.G.; Simpson, J.L.; Zhang, C.; Lu, J.; Sai, J.; et al. The Expression of IL-6, TNF- $\alpha$, and MCP-1 in Respiratory Viral Infection in Acute Exacerbations of Chronic Obstructive Pulmonary Disease. J. Immunol. Res. 2017, 2017, 8539294. [CrossRef] [PubMed]

124. Ishii, T.; Hosoki, K.; Nikura, Y.; Yamashita, N.; Nagase, T.; Yamashita, N. IFN Regulatory Factor 3 Potentiates Emphysematous Aggravation by Lipopolysaccharide. J. Immunol. 2017, 198, 3637-3649. [CrossRef] [PubMed]

125. Ding, L.; Morrison, S.J. Haematopoietic stem cells and early lymphoid progenitors occupy distinct bone marrow niches. Nature 2013, 495, 231-235. [CrossRef] [PubMed]

126. Gomperts, B.N.; Belperio, J.A.; Rao, P.N.; Randell, S.H.; Fishbein, M.C.; Burdick, M.D.; Strieter, R.M. Circulating progenitor epithelial cells traffic via CXCR4/CXCL12 in response to airway injury. J. Immunol. 2006, 176, 1916-1927. [CrossRef] [PubMed]

127. Hattori, K.; Heissig, B.; Tashiro, K.; Honjo, T.; Tateno, M.; Shieh, J.H.; Hackett, N.R.; Quitoriano, M.S.; Crystal, R.G.; Rafii, S.; et al. Plasma elevation of stromal cell-derived factor-1 induces mobilization of mature and immature hematopoietic progenitor and stem cells. Blood 2001, 97, 3354-3360. [CrossRef] [PubMed]

128. Salcedo, R.; Oppenheim, J.J. Role of chemokines in angiogenesis: CXCL12/SDF-1 and CXCR4 interaction, a key regulator of endothelial cell responses. Microcirculation 2003, 10, 359-370. [CrossRef] [PubMed]

129. Balabanian, K.; Lagane, B.; Infantino, S.; Chow, K.Y.C.; Harriague, J.; Moepps, B.; Arenzana-Seisdedos, F.; Thelen, M.; Bachelerie, F. The chemokine SDF-1/CXCL12 binds to and signals through the orphan receptor RDC1 in T lymphocytes. J. Biol. Chem. 2005, 280, 35760-35766. [CrossRef]

130. Dupin, I.; Thumerel, M.; Maurat, E.; Coste, F.; Eyraud, E.; Begueret, H.; Trian, T.; Montaudon, M.; Marthan, R.; Girodet, P.-O.; et al. Fibrocyte accumulation in the airway walls of COPD patients. Eur. Respir. J.. in press.

131. Liu, X.; Xie, C. Human endothelial progenitor cells isolated from COPD patients are dysfunctional. Mol. Cell. Biochem. 2012, 363, 53-63. [CrossRef]

132. Lim, K.; Hyun, Y.-M.; Lambert-Emo, K.; Capece, T.; Bae, S.; Miller, R.; Topham, D.J.; Kim, M. Neutrophil trails guide influenza-specific CD8+ T cells in the airways. Science 2015, 349, aaa4352. [CrossRef] [PubMed]

133. Dahl, M.; Tybjaerg-Hansen, A.; Vestbo, J.; Lange, P.; Nordestgaard, B.G. Elevated plasma fibrinogen associated with reduced pulmonary function and increased risk of chronic obstructive pulmonary disease. Am. J. Respir. Crit. Care Med. 2001, 164, 1008-1011. [CrossRef] [PubMed]

134. Dahl, M.; Vestbo, J.; Lange, P.; Bojesen, S.E.; Tybjaerg-Hansen, A.; Nordestgaard, B.G. C-reactive protein as a predictor of prognosis in chronic obstructive pulmonary disease. Am. J. Respir. Crit. Care Med. 2007, 175, 250-255. [CrossRef] [PubMed]

135. Cheng, D.T.; Kim, D.K.; Cockayne, D.A.; Belousov, A.; Bitter, H.; Cho, M.H.; Duvoix, A.; Edwards, L.D.; Lomas, D.A.; Miller, B.E.; et al. Systemic soluble receptor for advanced glycation endproducts is a biomarker of emphysema and associated with AGER genetic variants in patients with chronic obstructive pulmonary disease. Am. J. Respir. Crit. Care Med. 2013, 188, 948-957. [CrossRef] [PubMed]

136. Winkler, C.; Atochina-Vasserman, E.N.; Holz, O.; Beers, M.F.; Erpenbeck, V.J.; Krug, N.; Roepcke, S.; Lauer, G.; Elmlinger, M.; Hohlfeld, J.M. Comprehensive characterisation of pulmonary and serum surfactant protein D in COPD. Respir. Res. 2011, 12, 29. [CrossRef] [PubMed]

137. Coxson, H.O.; Dirksen, A.; Edwards, L.D.; Yates, J.C.; Agusti, A.; Bakke, P.; Calverley, P.M.; Celli, B.; Crim, C.; Duvoix, A.; et al. The presence and progression of emphysema in COPD as determined by CT scanning and biomarker expression: A prospective analysis from the ECLIPSE study. Lancet Respir. Med. 2013, 1, 129-136. [CrossRef] 
138. Lomas, D.A.; Silverman, E.K.; Edwards, L.D.; Miller, B.E.; Coxson, H.O.; Tal-Singer, R. Evaluation of COPD Longitudinally to Identify Predictive Surrogate Endpoints (ECLIPSE) investigators Evaluation of serum CC-16 as a biomarker for COPD in the ECLIPSE cohort. Thorax 2008, 63, 1058-1063. [CrossRef]

139. Faner, R.; Tal-Singer, R.; Riley, J.H.; Celli, B.; Vestbo, J.; MacNee, W.; Bakke, P.; Calverley, P.M.A.; Coxson, H.; Crim, C.; et al. Lessons from ECLIPSE: A review of COPD biomarkers. Thorax 2014, 69, 666-672. [CrossRef]

140. Baker, J.R.; Vuppusetty, C.; Colley, T.; Hassibi, S.; Fenwick, P.S.; Donnelly, L.E.; Ito, K.; Barnes, P.J. MicroRNA-570 is a novel regulator of cellular senescence and inflammaging. FASEB J. Off. Publ. Fed. Am. Soc. Exp. Biol. 2018, 33, 1605-1616. [CrossRef]

141. De Novaes Rocha, N.; de Oliveira, M.V.; Braga, C.L.; Guimarães, G.; de Albuquerque Maia, L.; de Araújo Padilha, G.; Silva, J.D.; Takiya, C.M.; Capelozzi, V.L.; Silva, P.L.; et al. Ghrelin therapy improves lung and cardiovascular function in experimental emphysema. Respir. Res. 2017, 18, 185. [CrossRef]

142. Wang, Y.; Zhou, Q.; Dong, L.; Xiong, M.; Jiang, H.; Guo, M.; Zhao, L.; Yuan, L.; Li, Z.; Liu, H.; et al. The effects of CXCL10 polymorphisms on COPD susceptibility. Mol. Genet. Genom. MGG 2018, 293, 649-655. [CrossRef] [PubMed]

143. Devine, S.M.; Flomenberg, N.; Vesole, D.H.; Liesveld, J.; Weisdorf, D.; Badel, K.; Calandra, G.; DiPersio, J.F. Rapid mobilization of CD34+ cells following administration of the CXCR4 antagonist AMD3100 to patients with multiple myeloma and non-Hodgkin's lymphoma. J. Clin. Oncol. Off. J. Am. Soc. Clin. Oncol. 2004, 22, 1095-1102. [CrossRef] [PubMed]

144. Gulick, R.M.; Lalezari, J.; Goodrich, J.; Clumeck, N.; DeJesus, E.; Horban, A.; Nadler, J.; Clotet, B.; Karlsson, A.; Wohlfeiler, M.; et al. Maraviroc for previously treated patients with R5 HIV-1 infection. N. Engl. J. Med. 2008, 359, 1429-1441. [CrossRef] [PubMed]

145. Hitchinson, B.; Eby, J.M.; Gao, X.; Guite-Vinet, F.; Ziarek, J.J.; Abdelkarim, H.; Lee, Y.; Okamoto, Y.; Shikano, S.; Majetschak, M.; et al. Biased antagonism of CXCR4 avoids antagonist tolerance. Sci. Signal. 2018, 11, eaat2214. [CrossRef] [PubMed]

146. Galzi, J.-L.; Hachet-Haas, M.; Bonnet, D.; Daubeuf, F.; Lecat, S.; Hibert, M.; Haiech, J.; Frossard, N. Neutralizing endogenous chemokines with small molecules. Principles and potential therapeutic applications. Pharmacol. Ther. 2010, 126, 39-55. [CrossRef] [PubMed]

147. Von Hundelshausen, P.; Agten, S.M.; Eckardt, V.; Blanchet, X.; Schmitt, M.M.; Ippel, H.; Neideck, C.; Bidzhekov, K.; Leberzammer, J.; Wichapong, K.; et al. Chemokine interactome mapping enables tailored intervention in acute and chronic inflammation. Sci. Transl. Med. 2017, 9, eaah6650. [CrossRef] [PubMed]

148. Mahler, D.A.; Huang, S.; Tabrizi, M.; Bell, G.M. Efficacy and safety of a monoclonal antibody recognizing interleukin-8 in COPD: A pilot study. Chest 2004, 126, 926-934. [CrossRef] [PubMed]

149. Dyer, D.P.; Thomson, J.M.; Hermant, A.; Jowitt, T.A.; Handel, T.M.; Proudfoot, A.E.I.; Day, A.J.; Milner, C.M. TSG-6 inhibits neutrophil migration via direct interaction with the chemokine CXCL8. J. Immunol. 2014, 192, 2177-2185. [CrossRef]

150. Stevenson, C.S.; Coote, K.; Webster, R.; Johnston, H.; Atherton, H.C.; Nicholls, A.; Giddings, J.; Sugar, R.; Jackson, A.; Press, N.J.; et al. Characterization of cigarette smoke-induced inflammatory and mucus hypersecretory changes in rat lung and the role of CXCR2 ligands in mediating this effect. Am. J. Physiol. Lung Cell. Mol. Physiol. 2005, 288, L514-L522. [CrossRef]

151. Thatcher, T.H.; McHugh, N.A.; Egan, R.W.; Chapman, R.W.; Hey, J.A.; Turner, C.K.; Redonnet, M.R.; Seweryniak, K.E.; Sime, P.J.; Phipps, R.P. Role of CXCR2 in cigarette smoke-induced lung inflammation. Am. J. Physiol. Lung Cell. Mol. Physiol. 2005, 289, L322-L328. [CrossRef]

152. Rennard, S.I.; Dale, D.C.; Donohue, J.F.; Kanniess, F.; Magnussen, H.; Sutherland, E.R.; Watz, H.; Lu, S.; Stryszak, P.; Rosenberg, E.; et al. CXCR2 Antagonist MK-7123. A Phase 2 Proof-of-Concept Trial for Chronic Obstructive Pulmonary Disease. Am. J. Respir. Crit. Care Med. 2015, 191, 1001-1011. [CrossRef] [PubMed]

153. Lazaar, A.L.; Miller, B.E.; Tabberer, M.; Yonchuk, J.; Leidy, N.; Ambery, C.; Bloomer, J.; Watz, H.; Tal-Singer, R. Effect of the CXCR2 antagonist danirixin on symptoms and health status in COPD. Eur. Respir. J. 2018, 52, 1801020. [CrossRef] [PubMed]

154. Planagumà, A.; Domènech, T.; Pont, M.; Calama, E.; García-González, V.; López, R.; Aulí, M.; López, M.; Fonquerna, S.; Ramos, I.; et al. Combined anti CXC receptors 1 and 2 therapy is a promising anti-inflammatory treatment for respiratory diseases by reducing neutrophil migration and activation. Pulm. Pharmacol. Ther. 2015, 34, 37-45. [CrossRef] [PubMed] 
155. Leaker, B.R.; Barnes, P.J.; O'Connor, B. Inhibition of LPS-induced airway neutrophilic inflammation in healthy volunteers with an oral CXCR2 antagonist. Respir. Res. 2013, 14, 137. [CrossRef] [PubMed]

156. Andrews, S.P.; Cox, R.J. Small Molecule CXCR3 Antagonists. J. Med. Chem. 2016, 59, 2894-2917. [CrossRef] [PubMed]

157. Takekoshi, T.; Ziarek, J.J.; Volkman, B.F.; Hwang, S.T. A locked, dimeric CXCL12 variant effectively inhibits pulmonary metastasis of CXCR4-expressing melanoma cells due to enhanced serum stability. Mol. Cancer Ther. 2012, 11, 2516-2525. [CrossRef] [PubMed]

158. Smith, E.W.; Liu, Y.; Getschman, A.E.; Peterson, F.C.; Ziarek, J.J.; Li, R.; Volkman, B.F.; Chen, Y. Structural analysis of a novel small molecule ligand bound to the CXCL12 chemokine. J. Med. Chem. 2014, 57, 9693-9699. [CrossRef] [PubMed]

159. Veldkamp, C.T.; Ziarek, J.J.; Peterson, F.C.; Chen, Y.; Volkman, B.F. Targeting SDF-1/CXCL12 with a ligand that prevents activation of CXCR4 through structure-based drug design. J. Am. Chem. Soc. 2010, 132, 7242-7243. [CrossRef] [PubMed]

160. Hachet-Haas, M.; Balabanian, K.; Rohmer, F.; Pons, F.; Franchet, C.; Lecat, S.; Chow, K.Y.C.; Dagher, R.; Gizzi, P.; Didier, B.; et al. Small neutralizing molecules to inhibit actions of the chemokine CXCL12. J. Biol. Chem. 2008, 283, 23189-23199. [CrossRef] [PubMed]

161. Hoellenriegel, J.; Zboralski, D.; Maasch, C.; Rosin, N.Y.; Wierda, W.G.; Keating, M.J.; Kruschinski, A.; Burger, J.A. The Spiegelmer NOX-A12, a novel CXCL12 inhibitor, interferes with chronic lymphocytic leukemia cell motility and causes chemosensitization. Blood 2014, 123, 1032-1039. [CrossRef]

162. Peng, D.; Cao, B.; Zhou, Y.-J.; Long, Y.-Q. The chemical diversity and structure-based evolution of non-peptide CXCR4 antagonists with diverse therapeutic potential. Eur. J. Med. Chem. 2018, 149, 148-169. [CrossRef] [PubMed]

163. McDermott, D.H.; Pastrana, D.V.; Calvo, K.R.; Pittaluga, S.; Velez, D.; Cho, E.; Liu, Q.; Trout, H.H.; Neves, J.F.; Gardner, P.J.; et al. Plerixafor for the Treatment of WHIM Syndrome. N. Engl. J. Med. 2019, 380, 163-170. [CrossRef] [PubMed]

164. Bonig, H.; Chudziak, D.; Priestley, G.; Papayannopoulou, T. Insights into the biology of mobilized hematopoietic stem/progenitor cells through innovative treatment schedules of the CXCR4 antagonist AMD3100. Exp. Hematol. 2009, 37, 402-415.e1. [CrossRef] [PubMed]

165. Cardones, A.R.; Murakami, T.; Hwang, S.T. CXCR4 enhances adhesion of B16 tumor cells to endothelial cells in vitro and in vivo via beta(1) integrin. Cancer Res. 2003, 63, 6751-6757. [PubMed]

166. Devi, S.; Wang, Y.; Chew, W.K.; Lima, R.; A-González, N.; Mattar, C.N.Z.; Chong, S.Z.; Schlitzer, A.; Bakocevic, N.; Chew, S.; et al. Neutrophil mobilization via plerixafor-mediated CXCR4 inhibition arises from lung demargination and blockade of neutrophil homing to the bone marrow. J. Exp. Med. 2013, 210, 2321-2336. [CrossRef] [PubMed]

167. Jujo, K.; Hamada, H.; Iwakura, A.; Thorne, T.; Sekiguchi, H.; Clarke, T.; Ito, A.; Misener, S.; Tanaka, T.; Klyachko, E.; et al. CXCR4 blockade augments bone marrow progenitor cell recruitment to the neovasculature and reduces mortality after myocardial infarction. Proc. Natl. Acad. Sci. USA 2010, 107, 11008-11013. [CrossRef] [PubMed]

168. Luo, Y.; Zhao, X.; Zhou, X.; Ji, W.; Zhang, L.; Luo, T.; Liu, H.; Huang, T.; Jiang, T.; Li, Y. Short-term intermittent administration of CXCR4 antagonist AMD3100 facilitates myocardial repair in experimental myocardial infarction. Acta Biochim. Biophys. Sin. 2013, 45, 561-569. [CrossRef] [PubMed]

(C) 2019 by the authors. Licensee MDPI, Basel, Switzerland. This article is an open access article distributed under the terms and conditions of the Creative Commons Attribution (CC BY) license (http://creativecommons.org/licenses/by/4.0/). 